\title{
Endogenous Serine Protease Inhibitor Modulates Epileptic Activity and Hippocampal Long-Term Potentiation
}

\author{
Andreas Lüthi, ${ }^{1}$ Herman van der Putten, ${ }^{2}$ Florence M. Botteri, ${ }^{5}$ Isabelle M. Mansuy, ${ }^{5}$ Marita Meins, ${ }^{5}$ \\ Uwe Frey, ${ }^{3}$ Gilles Sansig, ${ }^{2}$ Chantal Portet, ${ }^{2}$ Markus Schmutz, ${ }^{2}$ Markus Schröder, ${ }^{2}$ Cordula Nitsch, ${ }^{4}$ \\ Jean-Paul Laurent, ${ }^{1}$ and Denis Monard ${ }^{5}$
}

${ }^{1}$ Pharma Division, Preclinical Research, F. Hoffmann-La Roche Limited, CH-4002 Basel, Switzerland, 2Novartis Pharma, Research Department, CH-4002 Basel, Switzerland, 3Federal Institute for Neurobiology, D-39008 Magdeburg, Germany, 4/nstitute of Anatomy, Basel University, CH-4056 Basel, Switzerland, and 5Friedrich Miescher Institut, CH-4002 Basel, Switzerland

Protease nexin-1 (PN-1), a member of the serpin superfamily, controls the activity of extracellular serine proteases and is expressed in the brain. Mutant mice overexpressing $\mathrm{PN}-1$ in brain under the control of the Thy-1 promoter (Thy 1/PN-1) or lacking $\mathrm{PN}-1$ ( $\mathrm{PN}-1-/-)$ were found to develop epileptic activity in vivo and in vitro. Theta burst-induced long-term potentiation (LTP) and NMDA receptor-mediated synaptic transmission in the CA1 field of hippocampal slices were augmented in
Thy 1/PN-1 mice and reduced in $\mathrm{PN}-1-/-$ mice. Compensatory changes in GABA-mediated inhibition in Thy 1/PN-1 mice suggest that altered brain $\mathrm{PN}-1$ levels lead to an imbalance between excitatory and inhibitory synaptic transmission.

Key words: protease nexin-1; knock-out and transgenic mice; long-term potentiation; protease modulation; epileptiform activity; synaptical activity
The activity of extracellular serine proteases in the brain is controlled by specific inhibitors called serpins. Unlike the coagulation/fibrinolytic pathway where several different inhibitors are known, in the CNS only protease nexin-1 (PN-1; Guenther et al., 1985; Sommer et al., 1987) is present at significant levels (Mansuy et al., 1993; Sappino et al., 1993; Reinhard et al., 1994). PN-1 is expressed in both glial and neuronal cells of the developing and adult CNS (Mansuy et al., 1993; Sappino et al., 1993; Reinhard et al., 1994) and in glomeruli of the olfactory bulbs, where synapse formation and elimination remain an active process throughout life (Reinhard et al., 1988; Mansuy et al., 1993). High PN-1 expression also is detected after injury of the peripheral nervous system (Meier et al., 1989) or the CNS (Hoffmann et al., 1992; Scotti et al., 1994).

$\mathrm{PN}-1$ is a $43 \mathrm{kDa}$ protein that, when bound to the cell surface or the extracellular matrix (ECM), acts potently as a thrombin inhibitor (Stone et al., 1987; Wagner et al., 1989). PN-1 also can block plasmin, tissue plasminogen activator (tPA), urokinase plasminogen activator (uPA), and trypsin (Baker et al., 1980; Guen-

\footnotetext{
Received Sept. 9, 1996; revised Feb. 24, 1997; accepted April 8, 1997.

We thank Dr. A. Pavlik for dissecting brain regions; Dr. E. Reinhard for initial advice on the PN-1 immunoblot analysis; Dr. J. Moll for cloning and inserting the IL-1Ra cDNA into the Thy 1 expression cassette; Dr. A. Stief for initial advice and screening of transfected ES cells; Dr. M. Pozza for the gift of CGP57250; Drs. P. Caroni, J. Hagmann, D. Hartman, H.-R. Olpe, J. Nicholls, and A. Pavlik for critica reading of this manuscript; Mrs. M.-O. Schellinger for excellent care of the mice; Dr. S. Takeda for the wild-type neomycin gene; Dr. H. Blüthmann for the transgenic line carrying the neomycin gene; and C. Lapize and S. A. Leuenberger for valuable technical help.

Correspondence should be addressed to Dr. Denis Monard, Friedrich Miescher Institut, P.O. Box 2543, CH-4002 Basel, Switzerland.

Dr. Lüthi's present address: Department of Anatomy, School of Medical Sciences, University of Bristol, University Walk, Bristol BS8 1TD, UK.

Dr. Mansuy's present address: College of Physicians and Surgeons, Columbia University, 722 West 168th Street, New York, NY 10032.

Copyright (C) 1997 Society for Neuroscience 0270-6474/97/174688-12\$05.00/0
}

ther et al., 1985; Stone et al., 1987; Wagner et al., 1989), suggesting that in the brain PN-1 could modulate the activity of several serine proteases known to process or induce physiologically active macromolecules that control neurite extension (Krystosek and Seeds, 1981; Gurwitz and Cunningham, 1988; Jalink and Moolenaar, 1992; Suidan et al., 1992), neuronal cell viability (Smith-Swintosky et al., 1995; Tsirka et al., 1995; Vaughan et al., 1995), neuronal cell excitability (Yamada and Bilkey, 1993; Tsirka et al., 1995), and synaptic plasticity (Mansuy et al., 1993; Qian et al., 1993; Liu et al., 1994; Meiri et al., 1994; Romanic and Madri, 1994; Seeds et al., 1995; Frey et al., 1996; Huang et al., 1996).

To assess the physiological role of the equilibrium between PN-1 and its target protease(s), we disturbed the balance by generating transgenic mice that overexpress $\mathrm{PN}-1$ in the CNS under the control of the Thy 1 promoter (Thy $1 / \mathrm{PN}-1$ ) and transgenic mice that lack the $\mathrm{PN}-1$ gene $(\mathrm{PN}-1-/-)$. The Thy 1/PN-1 mutants should provide a model to study the effect of increased inhibition of serine protease(s), and the PN-1-/- mutants should provide a model for diminished serine protease inhibition. Because PN-1 can inhibit tPA, plasmin, and trypsin, previous findings led us to investigate the incidence of epileptic events in the mutant mice: (1) tPA-/- mice are less susceptible to kainic acid (KA)-induced seizures (Tsirka et al., 1995); (2) tPA is one of the genes upregulated on seizure induction (Qian et al., 1993), and it could be involved in the control of distinct forms of late long-term potentiation (L-LTP), depending on the particular tetanization paradigm (Frey et al., 1996; Huang et al., 1996); (3) plasminogen enhances the NMDA-induced increase in intracellular $\mathrm{Ca}^{2+}$ concentration (Inoue et al., 1994); and (4) trypsin induces epileptiform activity in hippocampal slices (Yamada and Bilkey, 1993). In this study we have used Thy $1 / \mathrm{PN}-1$ and PN$1-/-$ mice to evaluate the role of $\mathrm{PN}-1$ in epileptiform activity and in hippocampal synaptic transmission and plasticity. 


\section{MATERIALS AND METHODS}

Generation and analysis of Thy 1/PN-1 mice. An $8.2 \mathrm{~kb}$ EcoRI genomic DNA fragment (Evans et al., 1984) encompassing the murine Thy 1.2 gene was used to construct the Thy 1 expression cassette (a gift from Drs. Glen A. Evans and Shizhong Chen, Salk Institute, San Diego, CA). This cassette was generated originally by deleting a DNA fragment (from the BanI site in exon 2, upstream of the translation start codon, to a XhoI site in exon 4) and inserting an XhoI linker. A blunted HindIII-EcoRI DNA fragment containing the rat PN-1 cDNA (Sommer et al., 1987) was inserted into the blunted XhoI site of the Thy 1 cassette. The PN-1 cDNA encompasses the authentic PN-1 translation initiation (ATG) codon, signal peptide, and termination codon (TGA). Before DNA microinjection, the fusion genes were excised and freed from plasmid sequences by agarose gel electrophoresis and purified further with an Elutip-d column (Schleicher \& Schuell, Dassel, Germany). Transgenic mice were generated and analyzed as described before (Botteri et al., 1987). Male mice in each generation were used for breeding and maintenance of the Thy $1 / \mathrm{PN}-1$ lines (neither transgene is on the $\mathrm{X}$ chromosome). Both female and male heterozygous mice were used for analysis after the inheritance of the transgene by Southern blot analysis had been verified (Chen et al., 1987). In situ hybridization and Northern and immunoblot analyses were performed as described (Mansuy et al., 1993). Northern blots were hybridized to random-primed ${ }^{32} \mathrm{P}$-labeled DNA probes. The following probes were used: a $750 \mathrm{bp}$ XhoI-BamHI DNA fragment from exon 4 of the mouse Thy 1.2 gene (Ingraham et al., 1986) and a 1351 bp XhoI-XbaI DNA fragment carrying the rat PN-1 cDNA (Gloor et al., 1986; Sommer et al., 1987). For the thrombin inhibition assay, a previously described method (Nick et al., 1990) was adapted to microtiter plates. Calibration was performed by using rat recombinant PN-1 (Sommer et al., 1989).

Generation and analysis of PN-1-/- mice. Electroporation and PCR analysis of E14 embryonic stem (ES) cell clones resistant to G418 and gancyclovir were completed as previously described (Stief et al., 1994). ES cells carrying the disrupted PN-1 allele were injected into C57BL/6 recipient blastocysts (Stief et al., 1994) or cocultured with denuded post-compacted eight-cell-stage mouse embryos (Wood et al., 1993). Eight-cell embryos from $[(\mathrm{C} 57 \mathrm{BL} / 6 \times \mathrm{Balb} / \mathrm{c}) \mathrm{F} 1$ females $\times$ C57BL $/ 6$ males] at a post-compaction stage were placed in M2 medium (Hogan et al., 1986). Batches of 20 embryos were incubated briefly in acidified Tyrode's solution (Hogan et al., 1986) until dissolution of their zona pellucida. Meanwhile, ES cells were trypsinized to obtain a single-cell suspension. After preplating was done to remove most of the fibroblast feeder cells, the ES cells were resuspended at a concentration of $10^{6}$ cell $/ \mathrm{ml}$ in coculture medium (Wood et al., 1993). Ten zona-deprived embryos were placed in $50 \mu \mathrm{l}$ droplets of the ES cell suspension and incubated at $37^{\circ} \mathrm{C}$ for $2-3 \mathrm{hr}$ to allow random aggregation of ES cells with post-compaction embryos. Embryos were allowed to recover and develop overnight in M16 medium (Hogan et al., 1986); finally, they were transferred into pseudo-pregnant foster females. Male chimeras were mated with C57BL/6 females. The genotype of the mice was confirmed by Southern blot analysis.

Electrophysiology. Transverse hippocampal slices $(400 \mu \mathrm{m})$ from 6 - to 12 -week-old mutant mice and wild-type mice from the same litter were prepared by standard methods and maintained in an interface chamber. In the experiments that used extracellular field recordings, the slices were perfused at $35^{\circ} \mathrm{C}$ with a medium containing (in $\mathrm{mm}$ ): $\mathrm{NaCl} 124.0, \mathrm{KCl} 2.5$, $\mathrm{MgSO}_{4} 2.0, \mathrm{CaCl}_{2} 2.5, \mathrm{KH}_{2} \mathrm{PO}_{4}$ 1.25, $\mathrm{NaHCO}_{3} 26.0$, glucose 10, and sucrose 4 , bubbled with $95 \% \quad \mathrm{O}_{2} / 5 \% \mathrm{CO}_{2}, \mathrm{pH}$ 7.4. The CA1 stratum radiatum usually was stimulated by a bipolar platinum-iridium electrode (100 $\mu \mathrm{m}$ in diameter; $0.05 \mathrm{~Hz}, 100 \mu \mathrm{sec}$ pulse duration), and field EPSPs were recorded from the CA1 stratum radiatum or the stratum pyramidale by means of glass microelectrodes $(2 \mathrm{M} \mathrm{NaCl}, 1-5 \mathrm{M} \Omega)$. In the experiments investigating late LTP monopolar, laquer-coated stainless steel electrodes were used for stimulation and recording. Biphasic pulses $(0.1$ msec per polarity) were applied for testing. In the experiments that used the whole-cell voltage-clamp technique (Blanton et al., 1990) (HEKA EPC-9 patch-clamp amplifier), the slices were perfused at $28^{\circ} \mathrm{C}$ with the same extracellular medium, but the $\mathrm{MgSO}_{4}$ concentration was $1.3 \mathrm{~mm}$, the $\mathrm{KCl}$ concentration was $1.25 \mathrm{~mm}$, and $50 \mu \mathrm{M}$ picrotoxin was added to the medium throughout the experiment. The CA3 region routinely was removed to prevent bursting. Patch electrodes (3-8 M $\Omega$ ) were filled with a solution (280-290 mOsm) containing (in mM): Cs-methanesulphonate 130, $\mathrm{NaCl} 8$, HEPES 10, EGTA 5, Mg-ATP 2, Na-GTP 0.2, and QX-314 5 , pH-adjusted to 7.25 with $\mathrm{CsOH}$. Input and series resistance were monitored constantly, and cells showing $>10 \%$ change during the experiment were discarded. In the experiments that used the conventional intracellular recording technique, the slices were perfused at $30^{\circ} \mathrm{C}$ with the same medium as in the extracellular experiments, but the $\mathrm{KCl}$ concentration was $1.25 \mathrm{mM}$. Recordings were obtained in the discontinuous voltage-clamp mode (Axoclamp-2A amplifier) with sharp electrodes (60-90 M $\Omega$ ) filled with $4 \mathrm{M}$ potassium acetate; clamp efficiency was $80-85 \%$ in both experimental groups; stimulation intensity was adjusted to elicit maximal inhibitory currents. Statistical evaluations were performed by ANOVA and Student's $t$ test. All experiments and analyses were performed without knowledge of the respective genotypes of the animals. Results in the text or in the figures are expressed as mean \pm SEM.

\section{RESULTS}

\section{Generation and analysis of PN-1-overexpressing mice}

Elevated neuronal expression levels of rat PN-1 specifically in the CNS of transgenic mice were achieved by mouse Thy 1.2 regulatory sequences (Chen et al., 1987) to control expression of the rat PN-1 cDNA (Fig. 1A). From a total of four lines expressing the transgene, two were chosen for further studies. Line T1 expressed moderate and line T2 expressed high levels of PN-1. Individuals from each line and seven successive generations showed a stable pattern of brain-specific transgene mRNA expression (Fig. 1B). In these animals the tissue-specific expression pattern of the transgene was similar, but transgene mRNA levels were higher in brain of line T2 than T1 (Fig. $1 B$ ). Mice from both lines also showed low levels of transgene mRNA expression in lung (lane $L u$, Fig. $1 B$ ), but not in thymus, because of the lack of the thymocyte enhancer (Gordon et al., 1987; Vidal et al., 1990).

In both lines onset of transgene expression occurred around birth and by postnatal day 14 reached maximum levels that were retained throughout adult life (Fig. $1 C$ ). This pattern mimics the expression of the endogenous Thy 1 gene and offers the advantage of reducing the potential for triggering of compensating gene expression patterns during development. In agreement with this hypothesis, we observed no increases in the expression of tPA, uPA, or thrombin in Thy $1 / \mathrm{PN}-1$ mice.

Immunoblot analysis revealed that transgene expression led to a substantial increase in CNS PN-1 protein levels overall and in defined regions, including cerebellum, cortex, and hippocampus (Fig. 1D). Identification of transgene-derived rat PN-1 protein was facilitated by a slower migration of the endogenous mouse $\mathrm{PN}-1$ protein, as compared with the $43 \mathrm{kDa}$ rat $\mathrm{PN}-1$ protein (Mansuy et al., 1993). Like CNS transgene mRNA levels, PN-1 protein levels were approximately twofold higher in line T2, as compared with line T1. Functional activity of transgene-derived $\mathrm{PN}-1$ protein was assessed by testing brain homogenates for serine protease inhibitory activity (Fig. $1 E$ ). Compared with nontransgenic littermates, extracts of transgenic mouse brains consistently contained two- to fourfold more thrombin inhibitory activity. Moreover, the relative activities measured in various brain regions correlated with the amounts of PN-1 protein detected by immunoblot analysis (Fig. 1D) and with PN-1 immunoreactivity (Fig. 1G).

Endogenous PN-1 expression occurs in both neurons and glial cells (Mansuy et al., 1993; Reinhard et al., 1994). The predominantly neuronal expression of the transgene was confirmed by in situ hybridization with a rat PN-1 cRNA probe. High levels of transgene mRNA were detected in characteristic neuronal cell layers of the transgenic mouse brain (line T2). For reference, endogenous PN-1 mRNA expression was reflected by weak and diffuse hybridization signals in nontransgenic littermate brains (Fig. 1F; see also Mansuy et al., 1993). Transgene mRNA was particularly prominent in several layers of the neocortex, in the olfactory bulb, in the stratum pyramidale of all CA subfields in the 
A

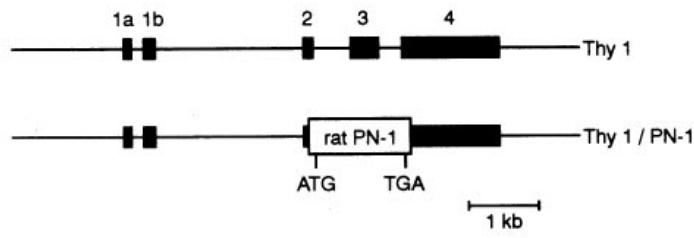

B

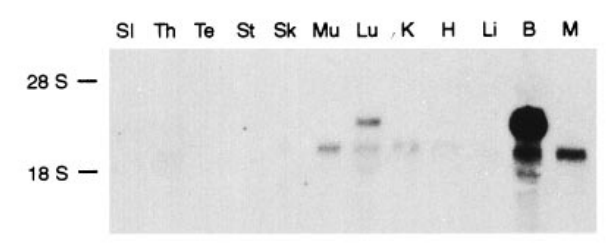

C

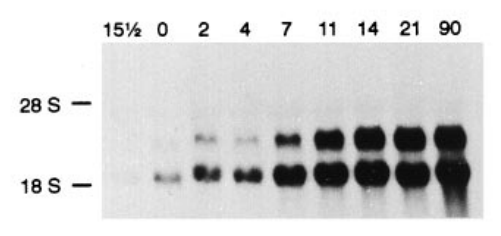

$\mathbf{F}$
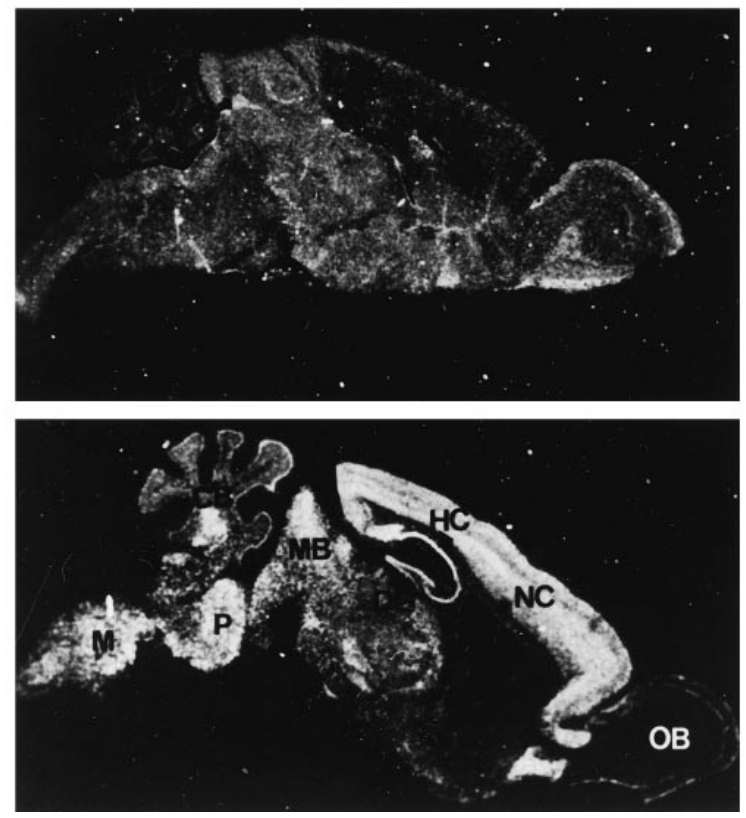

D

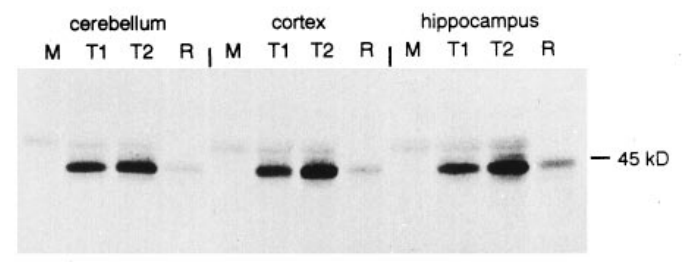

E

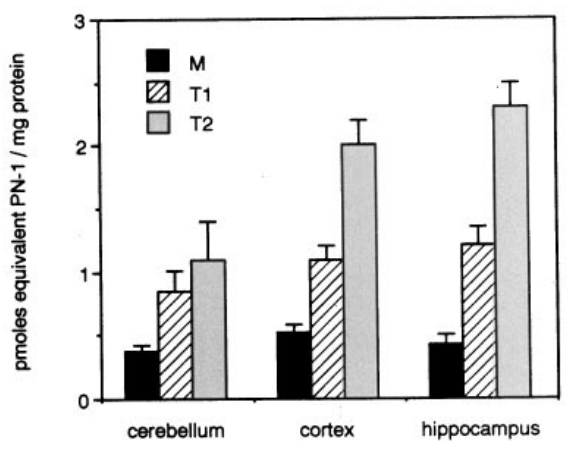

G
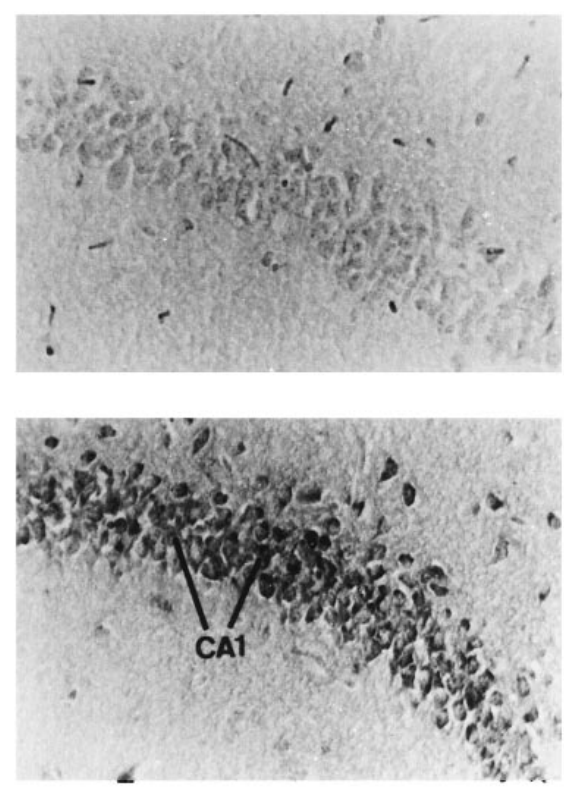

Figure 1. PN-1 transgene structure and neuronal expression of mRNA and protein. A, Top line, Genomic structure of the mouse Thy 1 gene, consisting of four exons depicted as solid boxes. Bottom line, Schematic diagram of the $8 \mathrm{~kb}$ DNA fragment containing the Thy 1/PN-1 fusion gene that was introduced into the mouse germ line. $B$, Northern blot analysis of total RNA $(10 \mu \mathrm{g} /$ lane $)$ extracted from brain $(B)$, liver $(L i)$, heart $(H)$, kidney $(K)$, lung $(L u)$, hind leg muscle $(M u)$, skin $(S k)$, stomach $(S t)$, testis $(T e)$, thymus $(T h)$, and small intestine $(S I)$ of an adult transgenic male of line T1. For comparison, lane $M$ contains $10 \mu \mathrm{g}$ of total brain RNA from an adult nontransgenic male mouse. The Northern blot was probed with ${ }^{32} \mathrm{P}-\mathrm{labeled}$ rat PN-1 cDNA (Sommer et al., 1987). The positions of $28 S$ and $18 S$ rRNAs are indicated on the left. C, Northern blot analysis showing the developmental expression pattern of the Thy 1/PN-1 and endogenous Thy 1 transcripts in line T1. The larger transcript represents the hybrid transgene mRNA. The smaller mRNA encodes endogenous mouse PN-1. The blot was probed with ${ }^{32} \mathrm{P}$-labeled mouse Thy 1 exon 4 probe. Total RNA (10 $\left.\mu \mathrm{g} / \mathrm{lane}\right)$ was isolated from heads of 15.5-d-old embryos and dissected brains at postnatal days $0,2,4,7,11,14,21$, and 90 . The positions of $28 S$ and $18 S$ rRNAs are indicated on the left. $D$, Tissue homogenates from different adult brain regions were subjected to immunoblot analysis. For comparison, protein homogenates from an adult nontransgenic mouse $(M)$ and rat $(R)$ also are included. The $45 \mathrm{kDa}$ molecular weight marker is indicated on the right. E, PN-1-equivalent activities (serine protease inhibitor activity) in protein homogenates from different brain regions of transgenic and nontransgenic adult mice (3 animals/line) were tested in a microtiter thrombin inhibition assay. The values shown are the means of three or four determinations \pm SEM. $F$, Sagittal brain sections $(10 \mu \mathrm{m})$ from adult nontransgenic (top picture) and transgenic (bottom picture; line T2) mice were processed for in situ hybridization with a ${ }^{35}$ S-labeled PN-1 cRNA probe. Transgene mRNA was detected in several layers of the neocortex $(N C)$, olfactory bulb $(O B)$, CA fields of the hippocampus $(H C)$, dentate gyrus $(D G)$, pons $(P)$, medulla $(M)$, midbrain $(M B)$, and cerebellum $(C B)$. The pattern obtained with the T1 line essentially was indistinguishable (data not shown). G, Sagittal sections $(10 \mu \mathrm{m})$ of hippocampus from adult nontransgenic (top picture) and line T2 transgenic (bottom picture) mice were processed for immunocytochemistry with the anti-rat PN-1 monoclonal antibody. Strong PN-1 immunoreactivity was detected in $C A 1$ neurons of transgenic mice. Results from line T1 essentially were indistinguishable (data not shown). 
hippocampus, in the dentate gyrus granule cells, in the cerebellar nuclei, and also in many neurons scattered throughout various brain regions, including pons, medulla, and midbrain (Fig. $1 F$ ). Using staining conditions that revealed little mouse endogenous PN-1 immunostaining in sections of control littermates (Mansuy et al., 1993; Reinhard et al., 1994), we detected a major increase in rat PN-1 protein levels in the hippocampus (Fig. 1G) and all other transgene mRNA-expressing cell populations (results not shown).

\section{Epileptic potential of Thy 1/PN-1 mice}

In wild-type mice intraperitoneal injection of the convulsive glutamate agonist kainic acid $(\mathrm{KA} ; 30 \mathrm{mg} / \mathrm{kg}$ ) was followed by clonic spasms of the forelegs in three of seven animals, with onset times ranging between 43 and $46 \mathrm{~min}$. In contrast, in littermate Thy 1/PN-1 mice (line T2) clonic spasms of the forelegs were observed in six of seven animals and full clonic spasms and chronic seizures in four of seven animals. Onset times ranged between 14 and 52 min (exitus, 3/7). These experiments suggest a clear increased susceptibility for kainic acid in the transgenic mice. Despite the fact that we used age-matched transgenic and nontransgenic littermates of similar weight $(25 \mathrm{gm})$, it is difficult to obtain statistically valid data by using the intraperitoneal injection of kainic acid. Effects caused by individual differences in kainic acid metabolism cannot be excluded. We therefore assessed whether Thy1/PN-1 mice showed increased susceptibility after stereotactic intrastriatal injection of another excitotoxin, ibotenic acid (0.3 $\mu \mathrm{l} / 10 \mathrm{~min} ; 1 \%$ solution in PBS). This procedure has usually negligible epileptic effects, and, as expected, no seizures were observed in the nontransgenic mice $(n=6)$. In contrast, all Thy $1 / \mathrm{PN}-1$ mice $(n=6)$ suffered from seizures. Histological evaluation of control and transgenic brains revealed no significant differences in injection site position and/or local tissue damage or appearance. Altogether, these observations suggest an increased susceptibility of Thy $1 / \mathrm{PN}-1$ mice to glutamatergic excitotoxins.

We also tested two convulsive agents that interfere mainly with GABAergic transmission. Intraperitoneal injection of isoniazid $(250 \mathrm{mg} / \mathrm{kg})$, the convulsant action of which is ascribed to a reduction of brain GABA levels via inhibition of glutamic acid decarboxylase (GAD), revealed a significant delay in seizure onset in the Thy $1 / \mathrm{PN}-1$ mice (line T2, $n=14$; median onset time, 56 min; Student's $t$ test, $p<0.01$ ) as compared with littermate control mice ( $n=14$; median onset time, $37 \mathrm{~min}$ ). In contrast, pentylenetetrazole (PTZ) was equally efficient in inducing seizures in transgenic and control mice when it was used at a threshold dose of $50 \mathrm{mg} / \mathrm{kg}$ ( $n=6$ for each group) or at a suprathreshold dose of $60 \mathrm{mg} / \mathrm{kg}$ ( $n=6$ for each group), whereas no seizures were observed in either group with a subthreshold dose of $40 \mathrm{mg} / \mathrm{kg}$ ( $n=15$ for each group). In summary, augmented levels of $\mathrm{PN}-1$ seem to increase seizure susceptibility evoked by glutamatergic excitotoxins, and the prolonged latency phase for isoniazid-induced convulsions would be compatible with an increase in GABAergic inhibition.

As an in vitro correlate of epileptic activity, we analyzed the potential of hippocampal slices to develop burst discharges, which are characterized by the appearance of multiple population spikes (polyspikes) in response to repetitive stimulation. These burst discharges are based on the activity-dependent disinhibition of excitatory synaptic transmission (Thompson and Gähwiler, 1989) and on the activation of NMDA receptors (Dingledine et al., 1986; Masukawa et al., 1991). Repetitive stimulation (1 Hz for 30 $\mathrm{sec})$ of the Schaffer collateral/commissural fibers provoked an
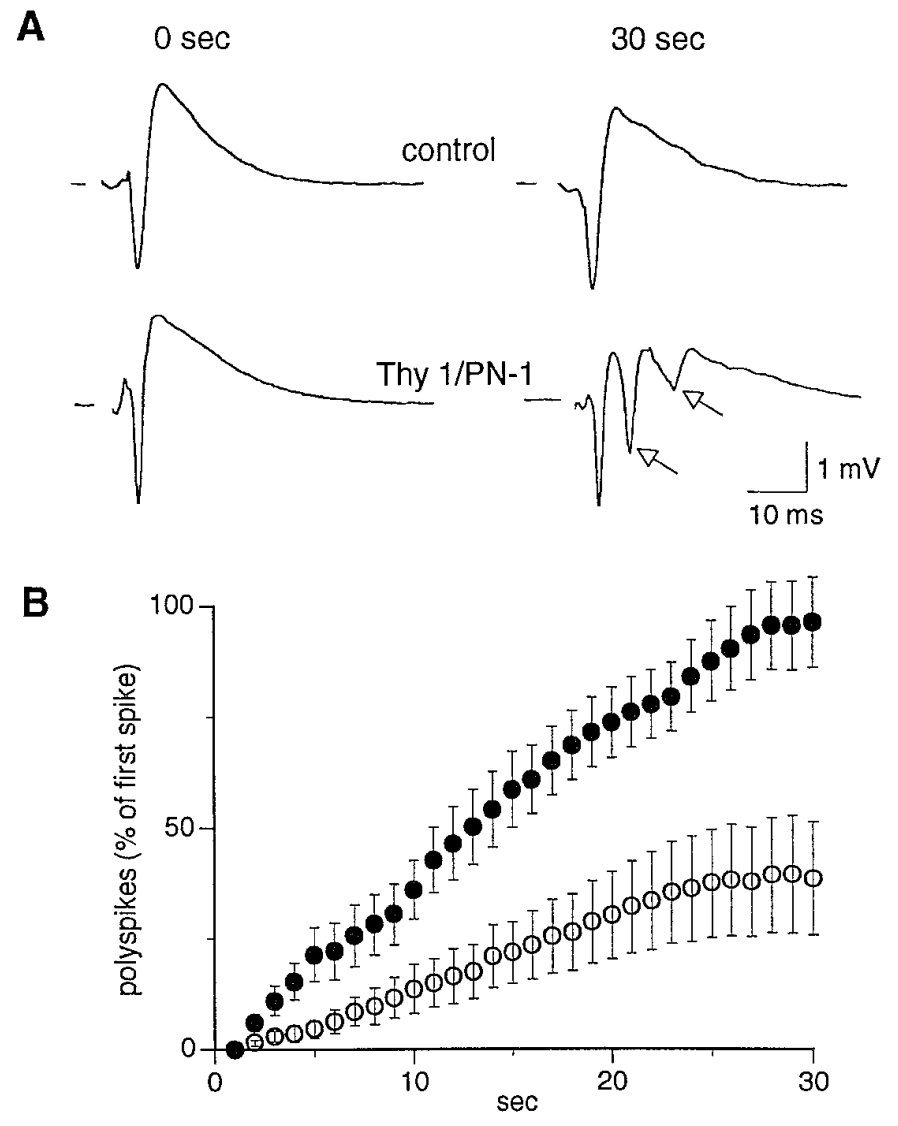

Figure 2. PN-1-overexpressing mice (Thy $1 / \mathrm{PN}-1$ ) exhibit in vitro epileptiform activity. $A$, Example of field potentials evoked by stimulation of the Schaffer collaterals and recorded in the stratum pyramidale of the CA1 area. With repetitive stimulation $(1 \mathrm{~Hz}$ for $30 \mathrm{sec})$, slices from Thy $1 / \mathrm{PN}-1$ mice exhibit an increase in polyspiking (i.e., multiple population spikes, arrow) in contrast to littermate control mice. $B$, Time course of the appearance of polyspikes during repetitive stimulation (area of the secondary spikes expressed as a percentage of the area of the first population spike) in slices from Thy $1 / \mathrm{PN}-1$ (solid symbols) and from littermate control mice (open symbols; $n=8$ animals $/ 8$ slices for each group; ANOVA, $p=0.01$ for area measurements).

increased polyspiking of the CA1 pyramidal neurons in Thy $1 / \mathrm{PN}-1$ mice, as compared with littermate controls $(n=8$ animals / 8 slices; ANOVA, $p<0.01$; Fig. $2 A, B)$. No bursting activity resembling interictal spikes was recorded, either spontaneously or at the normal test frequency of $0.05 \mathrm{~Hz}$.

In both in vivo and in vitro experiments mice expressing high levels of PN-1 thus developed epileptic activity on overactivation of the glutamatergic system.

\section{LTP in Thy $1 / \mathrm{PN}-1$ mice}

Basal synaptic transmission measured by the ratio between the presynaptic fiber volley and the corresponding initial slope of the field excitatory postsynaptic potential (fEPSP) was identical in Thy $1 / \mathrm{PN}-1$ mice and littermate wild-type controls $(0.24 \pm 0.03$ vs $0.24 \pm 0.02 \mathrm{msec}$ at maximal fEPSP amplitude; $n=6$ animals $/ 12$ slices). Paired-pulse facilitation, a short-term synaptic plasticity relying on presynaptic mechanisms (Hess et al., 1987), was unchanged in Thy $1 / \mathrm{PN}-1$ mice as well. These results suggest that overexpression of $\mathrm{PN}-1$ does not interfere with presynaptic release processes.

Induction of LTP at excitatory synapses facilitates the development of a seizure-prone state (for review, see McNamara, 1994). 
We have analyzed two different forms of LTP, theta burst stimulation (TBS)-induced LTP and induction of late LTP (L-LTP), using repeated strong tetanization. Recent observations reveal that both forms involve different cellular mechanisms (Frey et al., 1996; Huang et al., 1996). In the first set of experiments investigating TBS-induced stimulation, stimulation strength was adjusted to evoke a fEPSP of $30 \%$ of its maximum amplitude, which was identical in the two experimental groups $(0.24 \pm 0.02$ vs $0.23 \pm 0.02 \mathrm{mV} / \mathrm{msec} ; n=6$ animals $/ 12$ slices $)$. After stable baseline recording of fEPSPs for $20 \mathrm{~min}$, LTP was induced by a TBS paradigm (Larson and Lynch, 1986). LTP was increased significantly in Thy $1 / \mathrm{PN}-1$ mice when compared with their wildtype littermates $(199 \pm 12$ vs $166 \pm 7 \%, 50$ min after TBS; $n=6$ animals $/ 2$ slices; ANOVA, $p<0.05$; Fig. $3 A, B 1)$. This increase in LTP occurred without modifications in post-tetanic potentiation (Fig. 3A), a result that is in agreement with the unchanged paired-pulse facilitation. The postsynaptic responses to TBS showed a significant increase in Thy $1 / \mathrm{PN}-1$ mice, as compared with littermate controls $(n=6$ animals $/ 12$ slices; ANOVA, $p<$ 0.05 for area measurements; Fig. 3B2). This indicates that the enhancement of LTP is based on an increase in the postsynaptic responsiveness to the LTP-inducing stimulus. The present results were confirmed by monitoring LTP in a second transgenic line (line T1) overexpressing PN-1 and in a transgenic line overexpressing a different protein, the secreted mouse IL-1 receptor antagonist (Zahedi et al., 1991; Sauer et al., 1996), under control of the same Thy 1 expression cassette. Although LTP was increased to a similar extent in the second $\mathrm{PN}$-1-overexpressing line $\mathrm{T} 1$ ( $n=4$ animals $/ 8$ slices; $p<0.05$; results not shown), no differences from control values were observed in the transgenic mice overexpressing the IL- 1 receptor antagonist ( $n=4$ animals $/ 8$ slices; $p=0.24$; results not shown). Thus, the observed increase in LTP was not attributable to the use of the Thy 1 expression cassette per se, but it was attributable to the overexpression of $\mathrm{PN}-1$, leading to a selective increase in TBS-induced LTP.

Because tPA, one of the potential target proteases of PN-1, has been implicated directly in the long-term maintenance of LTP (Qian et al., 1993; Frey et al., 1996), a long-lasting form of LTP (L-LTP) also was recorded with an induction protocol specific for L-LTP (Frey et al., 1996). In contrast to TBS-induced LTP, L-LTP in Thy $1 / \mathrm{PN}-1$ and in littermate control mice was similar $(150 \pm$ 21 vs $138 \pm 18 \%, 8 \mathrm{hr}$ after induction; $n=5$ and 10 animals), suggesting no interference of PN-1 overexpression with the mechanisms of L-LTP maintenance.

\section{Excitatory synaptic transmission in Thy 1/PN-1 mice}

To study the mechanisms underlying the increase in polyspiking and in LTP, we first analyzed excitatory synaptic transmission by performing whole-cell patch-clamp recordings of evoked EPSCs in CA1 pyramidal cells in hippocampal slices. As illustrated in Figure 3,C and $D$, the voltage dependence and the reversal potential of both 6-cyano-7-nitroquinoxaline-2,3-dione (CNQX)sensitive non-NMDA receptor-mediated EPSCs (measured as the initial slope of dual-component EPSCs) and NMDA receptormediated EPSCs (in the presence of CNQX, $50 \mu \mathrm{M}$; Tocris Cookson, Bristol, UK) were not different in Thy $1 / \mathrm{PN}-1$ mice from their littermate control mice. The ratio between the NMDA and the non-NMDA receptor-mediated EPSCs measured at a holding potential of $-40 \mathrm{mV}$ was unchanged as well (Fig. $3 E$ ). In contrast, as illustrated in Figure $3 F$, the decay time course of NMDA receptor-mediated EPSCs recorded at $-40 \mathrm{mV}$ was prolonged significantly in Thy $1 / \mathrm{PN}-1$ mice, as compared with litter- mate control mice (time required to decay to $50 \%$ of the peak amplitude: $41.0 \pm 3.0$ vs $50.6 \pm 3.1 \mathrm{msec} ; n=7$ cells $/ 6$ animals; Student's $t$ test, $p<0.05)$. There was no change in the rise time of the NMDA currents. The prolonged decay time course was selective for the NMDA component, because the time course of the non-NMDA receptor-mediated component recorded at $-90 \mathrm{mV}$ was unchanged. Paired-pulse facilitation of NMDA receptormediated EPSCs recorded at $-60 \mathrm{mV}$ was similar in both experimental groups (results not shown), confirming the results we had obtained in extracellular recordings. In conclusion, the prolonged NMDA receptor-mediated EPSCs concur with the enhancement of TBS-induced LTP and the increased epileptic potential in Thy 1/PN-1 mice.

\section{Inhibitory synaptic transmission in Thy 1/PN-1 mice}

Because Thy $1 / \mathrm{PN}-1$ mice exhibited an increased onset latency to seizures induced by the GAD inhibitor isoniazid and because changes in GABA-mediated inhibition are known to influence seizure activity and/or LTP (Wigström and Gustafsson, 1983; Dingledine et al., 1986), we analyzed monosynaptic fast IPSCs in CA1 pyramidal cells, using conventional intracellular recording techniques. Recordings in the current-clamp mode revealed no difference in the resting membrane potential $(-64.9 \pm 2.2 /$ $-66.7 \pm 2.6 \mathrm{mV})$, the input resistance $(55 \pm 4 / 50 \pm 2 \mathrm{M} \Omega)$, the passive membrane time constant $(2.0 \pm 0.3 / 2.4 \pm 0.2 \mathrm{msec})$, or the shape/amplitude of the action potential between Thy $1 / \mathrm{PN}-1$ and littermate control mice. Discontinuous single-electrode voltage clamp was used to investigate $\mathrm{GABA}_{\mathrm{A}}$ receptor-mediated fast IPSCs in the presence of CNQX $(50 \mu \mathrm{M})$ and D-2-amino-5phosphonopentanoic acid (D-AP5, $25 \mu \mathrm{M}$; Tocris Cookson) to block excitatory synaptic transmission; slow IPSCs were blocked by $50 \mathrm{~mm}$ QX-314 (RBI, Natick, MA) in the recording electrode. Analysis of frequency-dependent paired-pulse depression (PPD) of monosynaptic fast IPSCs, under conditions that account for GABA acting on presynaptic $\mathrm{GABA}_{\mathrm{B}}$ receptors (Davies et al., $1990)$, revealed a small but significant reduction in paired-pulse depression ( $n=7$ cells from 6 animals; ANOVA, $p<0.05$; Fig. $4 A$ ). The reduction of PPD was not accompanied by changes in the voltage dependence, in the reversal potential, or in the maximal amplitude of the fast IPSC (Fig. 4B). There was also no change in the rise time of the IPSC and the membrane conductance during the IPSC (results not shown). However, the decay time course of the fast IPSC was significantly shorter in Thy $1 / \mathrm{PN}-1$ than in control mice (time required to decay to $50 \%$ of the peak amplitude, $28.6 \pm 3.7$ vs $40.6 \pm 4.0 \mathrm{msec} ; n=7$ cells from 6 animals; Student's $t$ test, $p<0.05$; Fig. $4 C$ ).

\section{Generation and analysis of PN-1-deficient mice}

So that the role of PN-1 in modulating neuronal excitability could be confirmed, mutant mice lacking a functional PN-1 gene were generated (Fig. 5). A targeting vector for disruption of the murine $\mathrm{PN}-1$ gene in mouse ES cells was constructed from two contiguous $129 \mathrm{~Sv} / \mathrm{J}$ genomic EcoRI DNA fragments spanning a total of 10.8 $\mathrm{kb}$ and harboring exons 2 and 3 of the PN-1 gene (Fig. $5 A$ ). Two of ten properly targeted ES cell clones were used to generate chimeric mice. Chimeric mice derived from either ES cell clone transmitted the mutant allele to male as well as female offspring $(\mathrm{PN}-1+/-)$, which subsequently were used to generate homozygous PN-1-/- mice. Successful disruption of the PN-1 gene was confirmed by Northern blot (Fig. $5 B$ ) and immunoblot analyses (Fig. $5 C$ ). Analysis of total brain RNA revealed an approximately twofold reduction in $\mathrm{PN}-1$ mRNA levels in $\mathrm{PN}-1+/-$ mice, as 
A

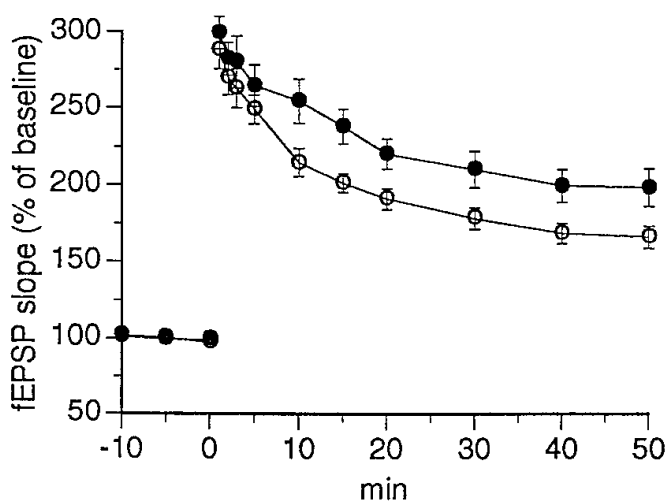

C

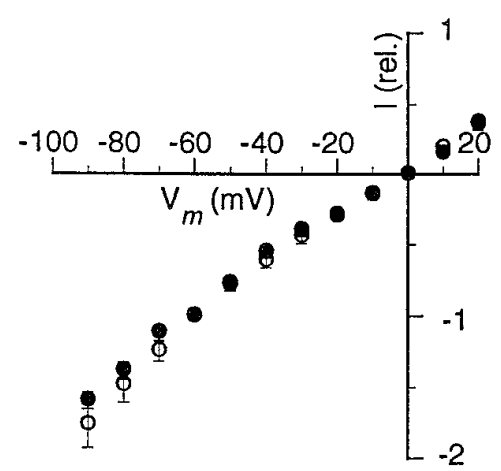

E

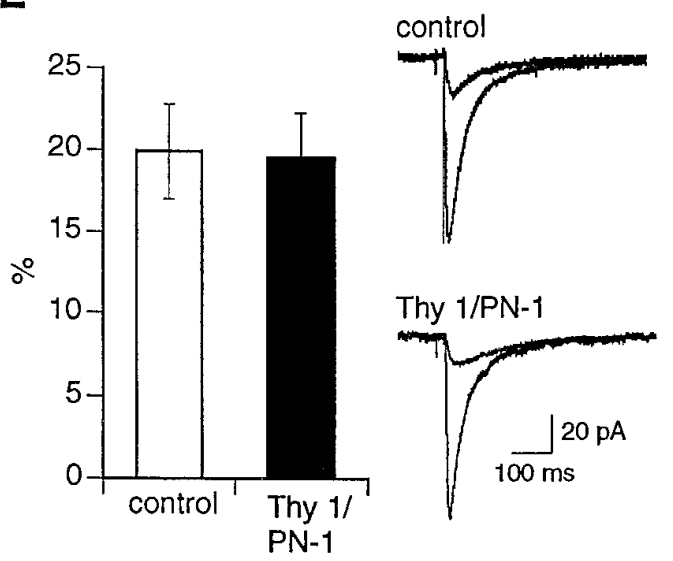

B1

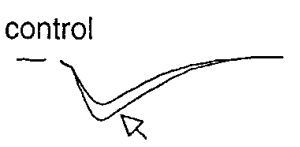

Thy $1 / \mathrm{PN}-1$

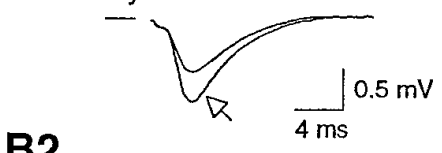

B2
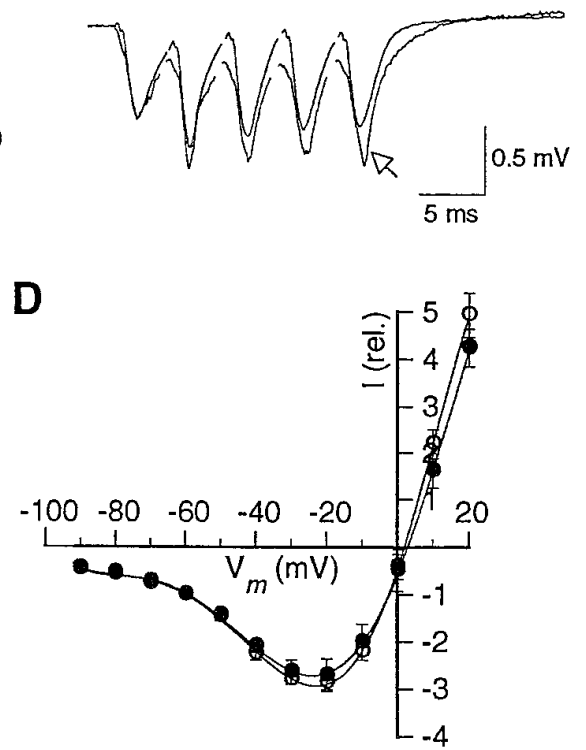

$\mathbf{F}$

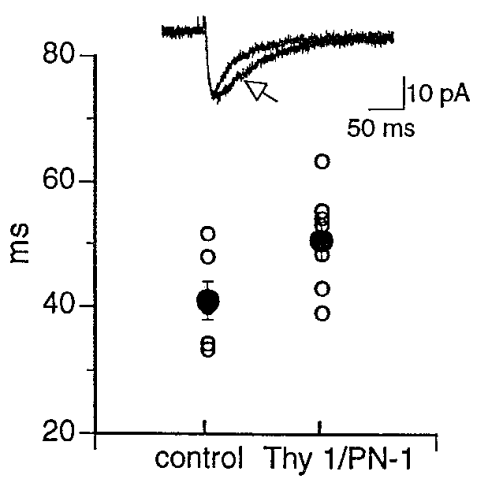

Figure 3. PN-1-overexpressing mice (Thy 1/PN-1) exhibit an enhanced LTP and a slower decay of NMDA receptormediated EPSCs. Data in $A$ and $B$ were obtained from extracellular recordings of field potentials. Data in $C-F$ were obtained from whole-cell recordings of evoked EPSCs. A, LTP of field EPSPs induced by theta burst stimulation (TBS) recorded in the CA1 stratum radiatum of slices from Thy $1 / \mathrm{PN}-1$ (solid symbols) and from littermate control mice (open symbols; $n=6$ animals $/ 12$ slices for each group; ANOVA, $p<$ $0.05)$. The baseline stimulation intensity was adjusted to evoke a fEPSP with an amplitude equal to $30 \%$ of its maximal amplitude (without superimposed population spike). LTP was induced by using a TBS paradigm (Larson and Lynch, 1986) consisting of two trains spaced by $8 \mathrm{sec}$. Duration of the stimulation pulses was doubled during TBS. B1, Averages of three consecutive fEPSPs recorded before and 50 min after TBS (arrow) in slices from Thy $1 / \mathrm{PN}-1$ and littermate control mice. B2, Superimposed postsynaptic bursts evoked by TBS in slices from Thy 1/PN-1 (arrow) and littermate control mice. $C$, Plot of the non-NMDA component of the synaptic EPSC (initial slope of the dual-component EPSC) versus holding potential recorded in CA1 pyramidal cells from Thy $1 / \mathrm{PN}-1$ (solid symbols; $n=8$ cells $/ 6$ animals) and from littermate control mice (open symbols; $n=7$ cells $/ 6$ animals). All values are normalized to the measurement obtained at $-60 \mathrm{mV}$. $D$, Plot of the peak amplitude of NMDA receptor-mediated EPSCs versus holding potential recorded in CA1 pyramidal cells from Thy 1/PN-1 (solid symbols) and littermate control mice (open symbols; $n=7$ cells $/ 6$ animals for each group). All values are normalized to the measurement obtained at $-60 \mathrm{mV}$. NMDA receptormediated EPSCs were recorded in the presence of $50 \mu \mathrm{M} \mathrm{CNQX}$ and could be blocked by $25 \mu \mathrm{M} \mathrm{D}(-)$-2-amino-5phosphonopentanoic acid (D-AP5). E, Ratios of peak NMDA receptormediated EPSCs to peak synaptic EPSCs (representing mainly the nonNMDA component) recorded at -40 $\mathrm{mV}$ ( $n=7$ cells $/ 6$ animals). The top traces show NMDA receptor-mediated EPSCs, and the bottom traces show synaptic EPSCs (averages of six consecutive sweeps) recorded at $-40 \mathrm{mV}$ in Thy 1/PN-1 and littermate control mice. $F$, Time required for NMDA receptormediated EPSCs (at $-40 \mathrm{mV}$ ) to decay to $50 \%$ of their peak amplitude $(n=7$ cells/ 6 animals; Student's $t$ test, $p<$ $0.05)$ in wild-type and Thy $1 / \mathrm{PN}-1$ mice (open symbols and solid symbols represent individual values and the mean \pm SEM, respectively). Sample traces are averages of six consecutive sweeps recorded at $-40 \mathrm{mV}$ in slices from Thy 1/PN-1 (arrow) and littermate control mice. 
A

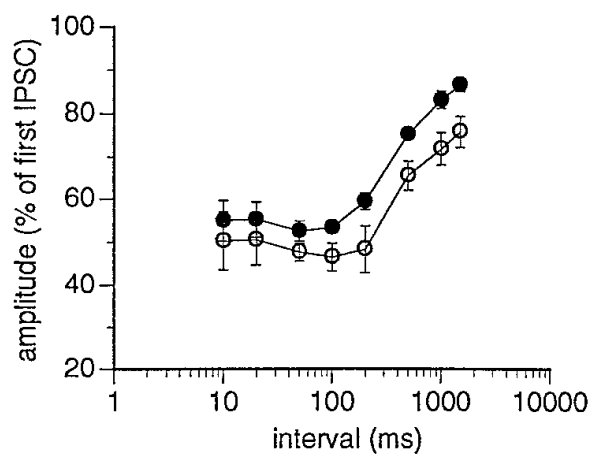

B

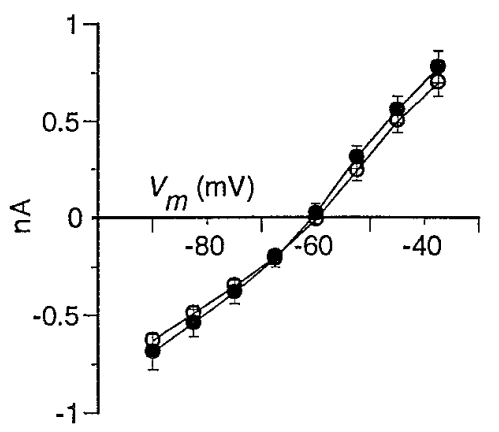

C
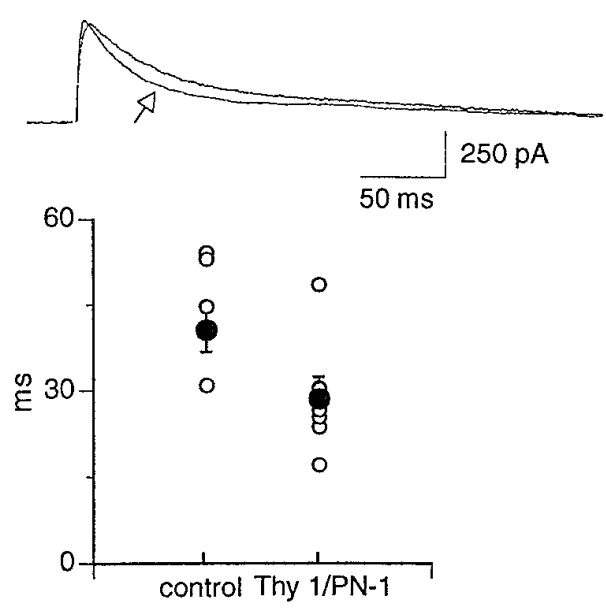

Figure 4. PN-1-overexpressing mice (Thy 1/PN-1) exhibit reduced paired-pulse depression, normal voltage dependence, and a more rapid decay of fast IPSCs. Data were obtained by conventional intracellular recordings in the discontinuous single-electrode voltage-clamp mode. $A$, Plot of the amplitude of the second IPSC as a percentage of the first IPSC recorded in CA1 pyramidal cells from Thy 1/PN-1 (solid symbols) and littermate control mice (open symbols) at a holding potential of $-55 \mathrm{mV}$ $(n=7$ cells $/ 6$ animals for each group; ANOVA, $p<0.05)$. Fast IPSCs were recorded in the presence of $50 \mu \mathrm{M}$ CNQX and $25 \mu \mathrm{M}$ D-AP5 in the perfusion medium. The recording electrode contained $50 \mathrm{~mm}$ QX-314 to block the slow IPSC. Fast IPSCs could be blocked by $50 \mu \mathrm{M}$ picrotoxin. $B$, Plot of the peak amplitude of maximal fast IPSCs versus holding potential. $C$, Time required for fast IPSCs (at $-55 \mathrm{mV}$ ) to decay to $50 \%$ of their peak amplitude $(n=7$ cells $/ 6$ animals; Student's $t$ test, $p<0.05$; open symbols and solid symbols represent individual values and the mean \pm SEM, respectively). Sample traces are averages of six consecutive sweeps recorded at $-55 \mathrm{mV}$ in slices from Thy $1 / \mathrm{PN}-1$ (arrow) and littermate control mice.
A

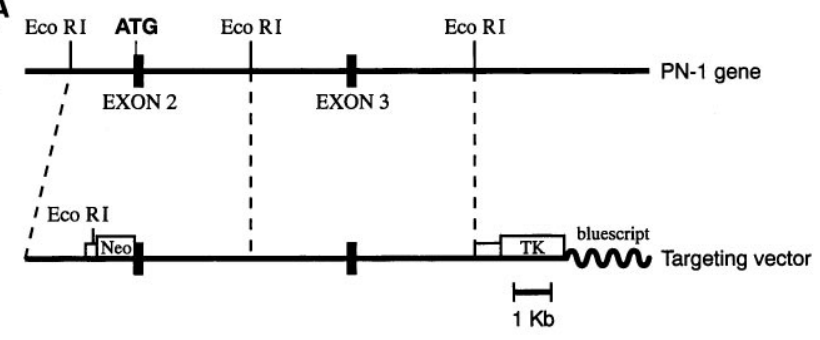

B

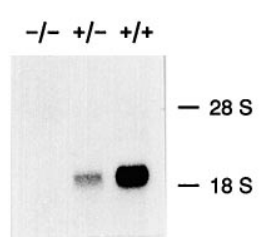

C

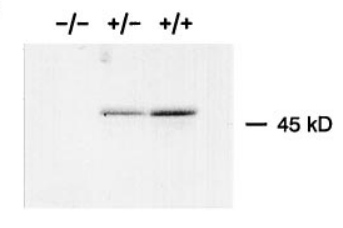

Figure 5. Production of PN-1-deficient mice (PN-1-/-) by homologous recombination in ES cells. $A$, Structures of the wild-type PN-1 gene and of the targeting vector. The $A T G$ initiation codon of the PN-1 gene was disrupted by insertion of a PyTKNeo expression cassette conferring G418 resistance in ES cells. Simultaneously, 99 bp of exon 2 were deleted. A herpes simplex virus (HSV) thymidine kinase (TK) expression cassette was added at the $3^{\prime}$ end of the $\mathrm{PN}-1$ homology region to allow for selection against random integration events. The linearized targeting vector was electroporated into E14 ES cells, and clones resistant to both G418 and gancyclovir were screened for homologous recombination events by PCR analysis. Of 80 individual ES cell clones, 12 proved potential candidates for the desired targeting event. Southern blot analysis with a PN-1 genomic DNA probe not contained within the targeting construct revealed that 10 of the 12 clones had the expected structure of a properly targeted PN-1 allele (data not shown). Neo, Neomycin expression cassette; TK, HSV thymidine kinase expression cassette; bluescript, vector sequences. PN-1 coding regions are indicated by filled boxes. B, Northern blot analysis of total RNA $(10 \mu \mathrm{g} /$ lane $)$ extracted from brain of homozygous PN-1deficient $(-/-)$, heterozygous $(+/-)$, and wild-type $(+/+)$ adult mice. The Northern blot was probed with ${ }^{32} \mathrm{P}-$ labeled rat PN-1 cDNA (Sommer et al., 1987). The positions of $28 S$ and $18 S$ rRNAs are indicated on the right. $C$, Immunoblot analysis of brain homogenates from homozygous PN-1 deficient $(-/-)$, heterozygous $(+/-)$, and wild-type $(+/+)$ adult mice, using the anti-rat PN-1 monoclonal antibody. The $45 \mathrm{kDa}(45 \mathrm{kD})$ molecular weight marker is indicated on the right.

compared with wild-type, and a complete lack of PN-1 transcripts in $\mathrm{PN}-1-/-$ mice (Fig. 5B). As expected, on Western blots no $\mathrm{PN}-1$ protein was detected in tissues from $\mathrm{PN}-1-/-$ mice (Fig. $5 C$ ). $\mathrm{PN}-1-/-$ mice were viable and showed no obvious gross abnormalities in health and behavior when compared with PN$1+/-$ and wild-type littermates.

\section{Epileptic potential, synaptic transmission, and LTP in PN-1-/- mice}

Similar to the Thy $1 / \mathrm{PN}-1$ mice, $\mathrm{PN}-1-/-$ mice showed an increased susceptibility to KA-induced seizures, as compared with genetically and age-matched control littermates. Intraperitoneal KA injection $(30 \mathrm{mg} / \mathrm{kg}$ ) was followed by full clonic spasms and seizures in 6 of $10 \mathrm{PN}-1-/-$ mice, with onset times ranging between 16 and $72 \mathrm{~min}$ (4/10, only forelegs involved). In contrast to the $\mathrm{PN}-1-/-$ mice, none of the littermate control animals exhibited full clonic spasms but showed only clonic spasms of the forelegs, with onset times ranging from 30 to $59 \mathrm{~min}(n=10)$. In vitro, hippocampal slices from $\mathrm{PN}-1-/-$ mice exhibited an increased polyspiking activity in the CA1 field on $1 \mathrm{~Hz}$ of stimulation, as compared with littermate controls $(n=5$ animals $/ 10$ slices; ANOVA, $p<0.05$; Fig. 6A,B).

Basal hippocampal synaptic transmission measured by the ratio 
A

0 sec

$30 \mathrm{sec}$
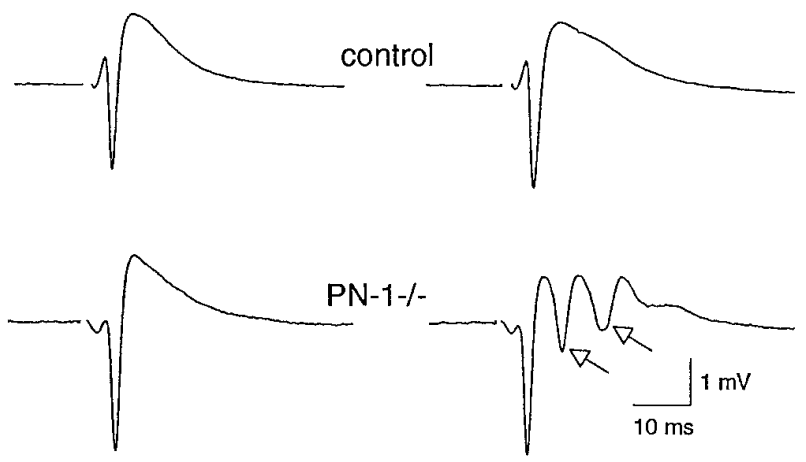

B

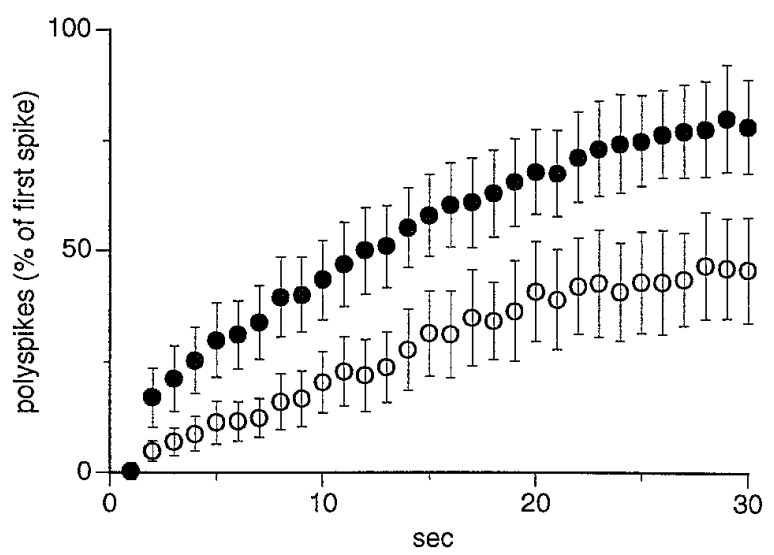

Figure 6. PN-1-deficient mice $(P N-1-/-)$ exhibit in vitro epileptiform activity. $A$, Example of field potentials evoked by stimulation of the Schaffer collaterals and recorded in the stratum pyramidale of the CA1 area. After repetitive stimulation ( $1 \mathrm{~Hz}$ for $30 \mathrm{sec}$ ), slices from $\mathrm{PN}-1-/-$ exhibit an increase in polyspiking (i.e., multiple population spikes, arrow) in contrast to littermate control mice. $B$, Time course of the appearance of polyspikes during repetitive stimulation (area of the secondary spikes expressed as a percentage of the area of the first population spike) in slices from $\mathrm{PN}-1-/-$ (solid symbols) and from littermate control mice (open symbols; $n=5$ animals/10 slices for each group; ANOVA, $p<0.05$ for area measurements).

between the presynaptic fiber volley and the corresponding initial slope of the fEPSP at Schaffer collateral/commissural $\rightarrow$ CA1 pyramidal cell synapses was similar in $\mathrm{PN}-1-/-$ and littermate control mice $(0.22 \pm 0.03$ vs $0.23 \pm 0.04 \mathrm{msec}$ at maximal fEPSP amplitude; $n=9$ animals $/ 13$ slices $)$. The absolute values of the fEPSP initial slope at the stimulation strength used to induce TBS-LTP (30\% of maximal fEPSP amplitude) were identical $(0.20 \pm 0.02$ vs $0.19 \pm 0.02 \mathrm{mV} / \mathrm{msec} ; n=9$ animals $/ 13$ slices $)$ Under these conditions LTP was found to be reduced in PN-1-/mice, as compared with littermate controls $(157 \pm 8$ vs $199 \pm$ 11\%, 50 min after TBS; $n=9$ animals $/ 13$ slices; ANOVA, $p<$ 0.05 ; Fig. $7 A, B 1)$. The postsynaptic responses to TBS were diminished, as compared with control mice $(n=9$ animals $/ 13$ slices; ANOVA, $p<0.05$ for area measurements; Fig. 7B2), suggesting that the reduction in LTP was a consequence of a less efficient TBS. Similar to the Thy $1 / \mathrm{PN}-1$ mice, no significant difference in the post-tetanic potentiation was measured. In contrast to TBSinduced LTP, the maintenance of L-LTP induced via stronger repeated tetanization was not influenced in $\mathrm{PN}-1-/-$ mice when compared with littermate controls $(168 \pm 11$ vs $161 \pm 11 \%$; $n=$ 7 animals/14 slices). Recently it was shown (Frey et al., 1996) that a different form of L-LTP can be observed in tPA-deficient mice, which simulated a "normal glutamatergic potentiation" by reduction of GABAergic inhibition. To test whether L-LTP in PN$1-/-$ mice is carried by similar mechanisms, we continuously applied the $\mathrm{GABA}_{\mathrm{A}}$-receptor inhibitor picrotoxin $(10 \mu \mathrm{M})$ before LTP induction. No differences were observed between mutant and wild-type animals $(123 \pm 8 \%, n=4$ from 4 animals vs $124 \pm 8 \%$, $n=6$ from 6 animals, $2 \mathrm{hr}$ after induction and during continuous application of picrotoxin).

Whole-cell recordings of evoked EPSCs from CA1 pyramidal cells in slices from $\mathrm{PN}-1-/-$ mice revealed no difference in the voltage dependence or the reversal potential of non-NMDA receptor-mediated (Fig. $7 C$ ) and NMDA receptor-mediated EPSCs (Fig. 7D). The decay time course of the NMDA receptormediated EPSCs recorded at $-40 \mathrm{mV}$ was not changed in PN$1-/-$ mice, as compared with littermate controls (Fig. $7 F$ ). However, in contrast to the Thy $1 / \mathrm{PN}-1$ mice, the ratio between the NMDA and the non-NMDA receptor-mediated EPSC was reduced markedly in $\mathrm{PN}-1-/-$ mice $(15.1 \pm 1.9$ vs $24.3 \pm 0.9 \%$; $n=7$ cells $/ 7$ and 6 animals; Student's $t$ test, $p<0.01$; Fig. 7E). These results are in agreement with a diminished postsynaptic response to the TBS and the consequent reduction in LTP, but they seem to contradict the increased epileptic potential observed in $\mathrm{PN}-1-/-$ mice.

\section{DISCUSSION}

\section{Lowered threshold for epileptic activity and enhancement of theta burst-induced LTP in PN-1- overexpressing mice}

In the hippocampus, epileptiform activity is based on extensive excitatory interactions among pyramidal cells (Miles and Wong, 1987; Meier and Dudek, 1993) and on reduction of synaptic inhibition, which promotes excitatory interactions and ultimately leads to excessive NMDA receptor activation (Dingledine et al., 1986; Merlin and Wong, 1993). In the CA1 field, synaptic activation of the NMDA receptors plays a primary role in the induction of epileptiform activity (Herron et al., 1985; Dingledine et al., 1986; Anderson et al., 1987) as well as in the induction of LTP (Harris et al., 1984) (for review, see Bliss and Collingridge, 1993). The observed enhancement of postsynaptic responses to TBS in Thy $1 / \mathrm{PN}-1$ mice suggested an increased activation of the NMDA receptor system. In agreement with this, we found that Thy 1/PN-1 mice exhibited a selectively prolonged decay time course of the NMDA receptor-mediated EPSCs. Interestingly, this decay time course is regulated developmentally, being slower in younger animals, which are also more prone to epilepsy (McDonald and Johnston, 1990; Carmignoto and Vicini, 1992; Hestrin, 1992). Moreover, the loss of susceptibility to LTP observed during the early development of the sensory cortex is accompanied by a shortening of the time course of NMDA receptor-mediated currents and by a decrease in the ratio between NMDA and nonNMDA receptor-mediated currents (Crair and Malenka, 1995). The decay kinetics of the NMDA receptor-mediated EPSC can vary according to the subunit composition of the NMDA receptor complex (Monyer et al., 1992). The prolonged time course of the EPSCs mediated by native NMDA receptors in neonates correlates with a higher expression of the NR2B subunit of the NMDA receptor during early development (Williams et al., 1993; Sheng et al., 1994). The subunit composition of endogenous NMDA receptors in Thy $1 / \mathrm{PN}-1$ mice remains to be determined.

The enhancement of NMDA receptor-mediated excitation in CA1 pyramidal cells was accompanied by modifications in GABAergic inhibition. Thy $1 / \mathrm{PN}-1$ mice exhibited a reduced 
Figure 7. PN-1-deficient mice $(P N$ $1-/-$ ) exhibit a reduced LTP and a decrease of the NMDA receptor-mediated component of the EPSC. Data in $A$ and $B$ were obtained from extracellular recordings of field potentials. Data in $C-F$ were obtained from whole-cell recordings of evoked EPSCs. $A$, LTP of field EPSPs induced by theta burst stimulation (TBS) recorded in the CA1 stratum radiatum of slices from $\mathrm{PN}-1-/-$ (solid symbols) and from littermate control mice (open symbols; $n=9$ animals $/ 13$ slices for each group; ANOVA, $p<$ $0.05)$. The baseline stimulation intensity was adjusted to evoke a fEPSP with an amplitude equal to $30 \%$ of its maximal amplitude (without superimposed population spike). LTP was induced as described in Figure 3. B1, Averages of three consecutive fEPSPs recorded before and $50 \mathrm{~min}$ after TBS (arrow) in slices from $P N-1-/-$ and littermate control mice. B2, Superimposed postsynaptic bursts evoked by TBS in slices from $\mathrm{PN}-1-/-$ and littermate control mice (arrow). $C$, Plot of the non-NMDA component of the synaptic EPSC (initial slope of the dual-component EPSC) versus holding potential recorded in CA1 pyramidal cells from $\mathrm{PN}-1-1-$ (solid symbols $n=7$ cells $/ 7$ animals) and from littermate control mice (open symbols; $n=7$ cells $/ 6$ animals). All values are normalized to the measurement obtained at $-60 \mathrm{mV}$. $D$, Plot of the peak amplitude of NMDA receptor-mediated EPSCs versus holding potential recorded in CA1 pyramidal cells from PN$1-/-$ (solid symbols; $n=7$ cells $/ 7$ animals) and from littermate control mice (open symbols; $n=7$ cells $/ 6$ animals). All values are normalized to the measurement obtained at $-60 \mathrm{mV}$. NMDA receptor-mediated EPSCs were recorded in the presence of $50 \mu \mathrm{M}$ CNQX and were blocked by $25 \mu \mathrm{M}$ D-AP5. E, Ratios of peak NMDA receptormediated EPSCs to peak synaptic EPSCs (representing mainly the nonNMDA component) recorded at -40 $\mathrm{mV}(n=7$ cells $/ 7$ and 6 animals; Student's $t$ test, $p<0.01$ ). The top traces show NMDA receptor-mediated EPSCs, and the bottom traces show synaptic EPSCs (averages of six consecutive sweeps) recorded at $-40 \mathrm{mV}$ in $P N-1-/-$ and littermate control mice. $F$, Time required for NMDA receptor-mediated EPSCs (at $-40 \mathrm{mV}$ ) to decay to $50 \%$ of their peak amplitude $(n=7$ cells $/ 7$ and 6 animals) in $\mathrm{PN}-1-/-$ and littermate control mice (open symbols and solid symbols represent individual values and the mean \pm SEM, respectively). Sample traces are averages of six consecutive sweeps recorded at $-40 \mathrm{mV}$ in slices from $P N-1-/-$ and from littermate control mice.
A

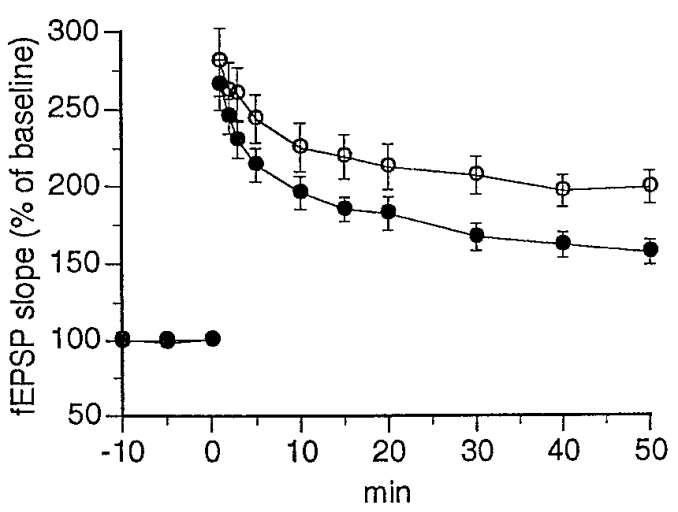

C

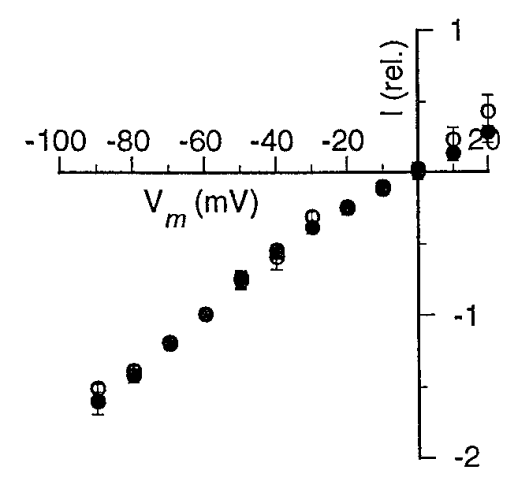

E

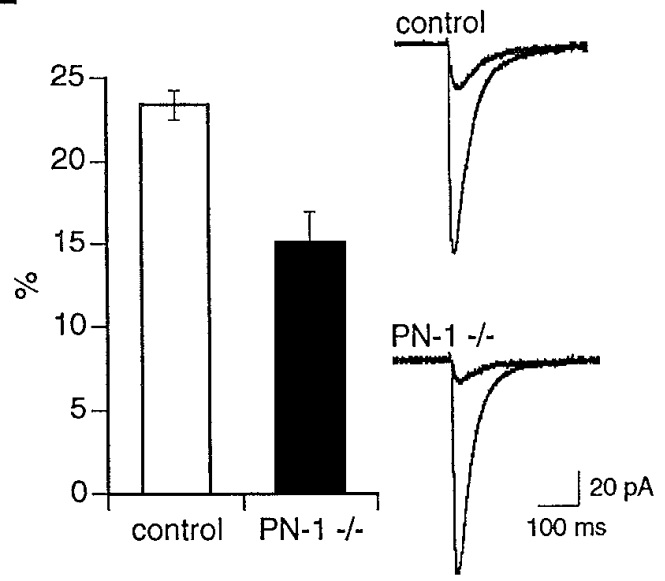

B1

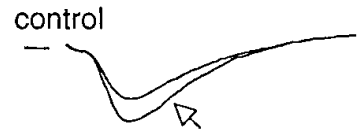

PN-1 -/-

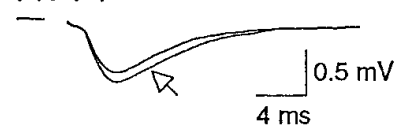

B2
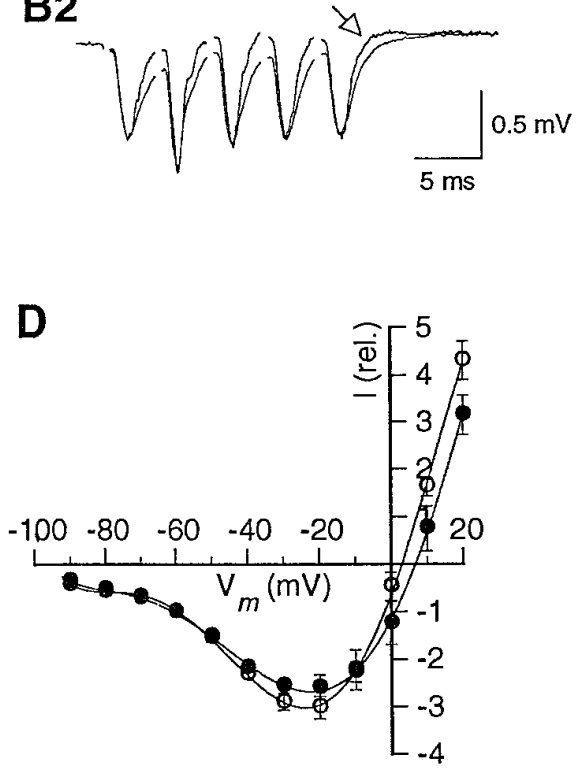

$\mathbf{F}$

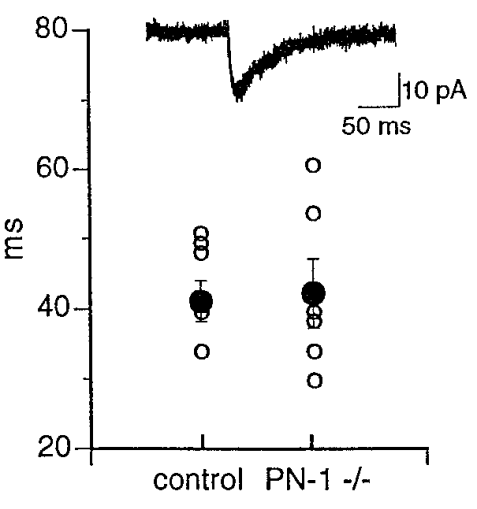

sensitivity to isoniazid-induced seizures, suggesting increased levels of GABA. In addition, the fast IPSC exhibited a shorter decay time course, as compared with littermate wild-type mice. Because the uptake of GABA is shaping the decay of the fast IPSC
(Dingledine and Korn, 1985), this suggests that chronically increased GABA levels might be compensated by a more rapid GABA uptake. Thy $1 / \mathrm{PN}-1$ mice also exhibited a reduction in the $\mathrm{GABA}_{\mathrm{B}}$ receptor-mediated autoinhibition of GABAergic synap- 
tic transmission. A similar reduction of the presynaptic autoinhibition at GABAergic nerve terminals leading to a frequencydependent increase in inhibition was observed in the dentate gyrus of kindled rats, a model for the temporal lobe epilepsy (Buhl et al., 1996). Our results suggest that in Thy $1 / \mathrm{PN}-1$ mice the increased neuronal excitability also has led to compensatory changes in GABAergic inhibition.

In contrast to the reduced activation of $\mathrm{GABA}_{\mathrm{B}}$ receptors on inhibitory nerve terminals, a reduction in the activation of $\mathrm{GABA}_{\mathrm{B}}$ receptors on excitatory nerve terminals could result in an increased excitability during repetitive stimulation (Isaacson et al., 1993). However, the finding that the paired-pulse facilitation of NMDA receptor-mediated EPSCs was similar in slices of Thy $1 / \mathrm{PN}-1$ mice, as compared with control animals (results not shown), argues against a significant change in GABAergic transmission at the heterosynaptic level, unlike in lethargic mice, a genetic model for absence seizures (Hosford et al., 1992).

Eventually a reduced autoinhibition at GABAergic nerve terminals paradoxically may lead to a frequency-dependent hyperexcitation. During TBS the large inhibitory chloride currents may reverse into excitatory outward currents, a phenomenon attributed to compartmentalized shifts in $E_{\mathrm{Cl}}$ within the neurons (Alger and Nicoll, 1982; Thompson and Gähwiler, 1989). Moreover, a shortened time course of the GABA concentration in the extracellular space also should result in less spillover of GABA to the neighboring synaptic terminals (Isaacson et al., 1993) and eventually lead to a net reduction of GABAergic inhibition of the CA1 pyramidal neurons. A more detailed analysis of GABAergic inhibition, however, is needed to assess fully its contribution to the observed effects in Thy $1 / \mathrm{PN}-1$ mice.

\section{Lowered threshold for epileptic activity and diminution of theta burst-induced LTP in PN-1-deficient mice}

In $\mathrm{PN}-1-/-$ mice the susceptibility to KA-induced seizures and the in vitro epileptiform activity was increased, but in contrast to Thy $1 / \mathrm{PN}-1$ mice TBS-induced LTP was reduced and accompanied by a diminished postsynaptic response to TBS. In agreement with this, we found that the ratio between the NMDA receptormediated and the non-NMDA receptor-mediated components of the synaptic EPSC was reduced in $\mathrm{PN}-1-/-$ mice. This may reflect a reduced number of functionally active synaptic NMDA receptors or a change in the subunit composition (Sakimura et al., 1995). The enhancement and the reduction in LTP in PN-1overexpressing and deficient mice, respectively, are in line with the observed changes in NMDA receptor-mediated synaptic transmission. In contrast to TBS-induced LTP, no changes were found of L-LTP induced via a strong tetanization. This particular stimulation protocol might involve different and/or additional events, such as the activation of voltage-dependent calcium channels and the subsequent influx of the calcium required for L-LTP. More subtle changes at the NMDA receptor could be covered by these processes and therefore are indistinguishable in these experiments. However, it is clear that $\mathrm{PN}-1-/-$ mice, although exhibiting a reduced NMDA component, were more susceptible to KA-induced seizures and showed an increased in vitro epileptiform activity, as compared with littermate controls. This might be attributable to a reduced excitation of the inhibitory interneurons or to nonsynaptic mechanisms, such as modifications in the extracellular space (Hochman et al., 1995), in the extracellular matrix, or in the fine wiring of the neuronal network propagating seizures (McNamara, 1994). Whatever the mechanisms, a reduc- tion of LTP does not necessarily imply an overall reduced excitability; e.g., mice lacking the $\alpha$-subunit of calcium/calmodulin kinase II exhibit a severe limbic epilepsy despite a deficient LTP (Silva et al., 1992; Butler et al., 1995), and mice lacking the prion protein also showed decreased LTP and increased epileptiform activity (Collinge et al., 1994).

\section{Molecular mechanisms of PN-1-induced changes in neuronal excitability}

PN-1 can inhibit several proteases, such as tPA and thrombin, which play a critical role in extracellular matrix remodeling (Romanic and Madri, 1994). The interaction of cells with the extracellular matrix not only regulates cell shape, motility, differentiation, and gene expression via integrin-mediated signal transduction (Schwartz et al., 1995) but also modifies transmitter release (Chen and Grinnell, 1995), hippocampal LTP (Staubli et al., 1990; Xiao et al., 1991), and kindling (Grooms and Jones, 1995) (for review, see Jones, 1996).

In the hippocampus, tPA is upregulated after seizures, kindling, or LTP (Qian et al., 1993). However, tPA-catalyzed proteolysis has been detected throughout most regions of the hippocampus except in the CA1 field because of the presence of an inhibitory activity (Sappino et al., 1993). mRNA analysis of three putative tPA inhibitors (PAI-1, PAI-2, and PN-1) indicated that PN-1 is the only potential candidate (Sappino et al., 1993). The increase in GABAergic inhibition in $\mathrm{tPA}-/-$ mice (Frey et al., 1996) concurs with our finding that inhibition also is enhanced in Thy $1 / \mathrm{PN}-1$ mice. In addition, the decreased sensitivity of tPA-/ - mice to KA-induced seizures (Tsirka et al., 1995) fits with the increased susceptibility of $\mathrm{PN}-1-/-$ mice but provides at the same time a counter-argument for the action of $\mathrm{PN}-1$ on tPA in Thy $1 / \mathrm{PN}-1$ mice. Moreover, neither an excess nor an absence of PN-1 significantly altered tPA-mediated proteolysis, as detected by zymographic overlay assays performed on cryostat hippocampal sections derived from both $\mathrm{PN}-1-/-$ and Thy $1 / \mathrm{PN}-1$ mice (results not shown).

Alternatively, PN-1 might act on a thrombin-like protease and interfere with the activation of the thrombin receptor (Dihanich et al., 1991; Niclou et al., 1994), which has been shown to promote the secretion of thrombospondin-1 (TSP1), an extracellular matrix component also upregulated after KA-induced seizures (Chamak et al., 1994). TSP1 is a ligand for the $\alpha 3 / \beta 1$ integrin (DeFreitas et al., 1995) and can inhibit plasmin and, like PN-1, uPA (Hogg, 1994). NMDA receptor-mediated neuronal excitability has been shown to be enhanced by plasmin (Inoue et al., 1994), and uPA-overexpressing mice exhibit learning deficits (Meiri et al., 1994). Thus, complex protease-dependent extracellular interactions relevant to neuronal plasticity may be influenced by the level of PN-1 expression.

In conclusion, we have shown that synaptic plasticity, as measured by theta burst-induced LTP, correlates with the level of $\mathrm{PN}-1$ in the brain of mutant mice and that the respective change in this form of LTP can be explained by opposite modifications of NMDA receptor-mediated synaptic transmission with no change in basal non-NMDA receptor-mediated synaptic transmission. The lowered threshold for epileptiform activity in both PN-1overexpressing and deficient mice indicates that the equilibrium between brain serine proteases and their inhibitors, like PN-1, contributes to the balance between excitation and inhibition during sustained neuronal activity. 


\section{REFERENCES}

Alger BE, Nicoll RA (1982) Feed-forward dendritic inhibition in rat hippocampal pyramidal cells studied in vitro. J Physiol (Lond) 328:105-123.

Anderson WW, Swartzwelder HS, Wilson WA (1987) The NMDA receptor antagonist 2-amino-5-phosphonovalerate blocks stimulus traininduced epileptogenesis but not epileptiform bursting in the rat hippocampal slice. J Neurophysiol 57:1-21.

Baker JB, Low DA, Simmer RL, Cunningham DD (1980) Protease nexin: a cellular component that links thrombin and plasminogen activator and mediates their binding to cells. Cell 21:37-45.

Blanton M, LoTurco J, Kriegstein A (1990) Whole-cell recording from neurons in slices of reptilian and mammalian cortex. J Neurosci Methods 30:203-210.

Bliss TVP, Collingridge GL (1993) A synaptic model of memory: longterm potentiation in the hippocampus. Nature 361:31-39.

Botteri FM, van der Putten H, Wong DF, Sauvage CA, Evans RM (1987) Unexpected thymic hyperplasia in transgenic mice harboring a neuronal promoter fused with simian virus 40 large $\mathrm{T}$ antigen. Mol Cell Biol 7:3178-3184.

Buhl EH, Otis TS, Mody I (1996) Zinc-induced collapse of augmented inhibition by GABA in a temporal lobe epilepsy model. Science 271:369-373.

Butler LS, Silva AJ, Abeliovich A, Watanabe Y, Tonegawa S, McNamara JO (1995) Limbic epilepsy in transgenic mice carrying a $\mathrm{Ca}^{2+}$ calmodulin-dependent kinase-II $\alpha$-subunit mutation. Proc Natl Acad Sci USA 92:6852-6855.

Carmignoto G, Vicini S (1992) Activity-dependent decrease in NMDA receptor responses during development of the visual cortex. Science 258:1007-1011.

Chamak B, Morandi V, Mallat M (1994) Brain macrophages stimulate neurite outgrowth and regeneration by secreting thrombospondin. J Neurosci Res 38:221-233.

Chen BM, Grinnell AD (1995) Integrins and modulation of transmitter release from motor nerve terminals by stretch. Science 269:1578-1580.

Chen S, Botteri FM, van der Putten H, Landel CP, Evans GA (1987) A lymphoproliferative abnormality associated with inappropriate expression of the Thy-1 antigen in transgenic mice. Cell 51:7-19.

Collinge J, Whittington MA, Sidle KCL, Smith CJ, Palmer MS, Clarke AR, Jefferys JGR (1994) Prion protein is necessary for normal synaptic function. Nature 370:295-297.

Crair MC, Malenka RC (1995) A critical period for long-term potentiation at thalamocortical synapses. Nature 375:325-328.

Davies CH, Davies SN, Collingridge GL (1990) Paired-pulse depression of monosynaptic GABA-mediated inhibitory postsynaptic responses in rat hippocampus. J Physiol (Lond) 424:513-531.

DeFreitas MF, Yoshida CK, Frazier WA, Mendrick DL, Kypta RM, Reichardt LF (1995) Identification of integrin $\alpha 3 \beta 1$ as a neuronal thrombospondin receptor mediating neurite outgrowth. Neuron 15:333-343.

Dihanich M, Kaser M, Reinhard E, Cunningham D, Monard D (1991) Prothrombin mRNA is expressed by cells of the nervous system. Neuron 6:575-581.

Dingledine R, Korn SJ (1985) $\gamma$-Aminobutyric acid uptake and the termination of inhibitory synaptic potentials in the rat hippocampal slice. J Physiol (Lond) 366:387-409.

Dingledine R, Hynes MA, King GL (1986) Involvement of $N$-methyl-Daspartate receptors in epileptiform bursting in the rat hippocampal slice. J Physiol (Lond) 380:175-189.

Evans GA, Ingraham HA, Lewis K, Cunningham K, Seki T, Moriuchi T, Chang HC, Silver J, Hyman R (1984) Expression of the Thy-1 glycoprotein gene by DNA-mediated gene transfer. Proc Natl Acad Sci USA 81:5542-5536.

Frey U, Müller M, Kuhl D (1996) A different form of long-lasting potentiation revealed in tissue plasminogen activator mutant mice. J Neurosci 16:2057-2063.

Gloor S, Odink K, Guenther J, Nick H, Monard D (1986) A glia-derived neurite-promoting factor with protease inhibitory activity belongs to the protease nexins. Cell 47:687-693.

Gordon JW, Chesa PG, Nishimura H, Rettig WJ, Maccari JE, Endo T, Seravalle E, Seki T, Silver J (1987) Regulation of Thy-1 gene expression in transgenic mice. Cell 50:445-452.

Grooms S, Jones LS (1995) RGDS tetrapeptide facilitates hippocampal in vitro kindling: evidence for integrin-mediated physiological stability. Soc Neurosci Abstr 21:772.
Guenther J, Nick H, Monard D (1985) A glia-derived neurite-promoting factor with protease inhibitory activity. EMBO J 4:1963-1966.

Gurwitz D, Cunningham DD (1988) Thrombin modulates and reverses neuroblastoma neurite outgrowth. Proc Natl Acad Sci USA 85:34403444.

Harris EW, Ganong AH, Cotman CW (1984) Long-term potentiation in the hippocampus involves activation of $N$-methyl-D-aspartate receptors. Brain Res 323:132-137.

Herron CE, Williamson R, Collingridge GL (1985) A selective $N$-methylD-aspartate antagonist depresses epileptiform activity in rat hippocampal slices. Neurosci Lett 61:255-260.

Hess G, Kuhnt U, Voronin LL (1987) Quantal analysis of paired-pulse facilitation in guinea pig hippocampal slices. Neurosci Lett 77:187-192.

Hestrin S (1992) Developmental regulation of NMDA receptormediated synaptic currents at a central synapse. Nature 357:686-689.

Hochman DW, Baraban SC, Owens JWM, Schwartzkroin PA (1995) Dissociation of synchronization and excitability in furosemide blockade of epileptiform activity. Science 270:99-102.

Hoffmann MC, Nitsch C, Scotti AL, Reinhard E, Monard D (1992) The prolonged presence of glia-derived nexin, an endogenous protease inhibitor, in the hippocampus after ischaemia-induced delayed neuronal death. Neuroscience 49:397-408.

Hogan B, Costantini F, Lacy E (1986) Manipulating the mouse embryo: a laboratory manual. Cold Spring Harbor, NY: Cold Spring Harbor Laboratory.

Hogg PJ (1994) Thrombospondin-1 as an enzyme inhibitor. Thromb Haemost 72:787-792.

Hosford DA, Clark S, Cao Z, Wilson WA, Lin F, Morrisett RA, Huin A (1992) The role of $\mathrm{GABA}_{\mathrm{B}}$ receptor activation in absence seizures of lethargic (lh/lh) mice. Science 257:398-401.

Huang YY, Bach ME, Lipp HP, Zhuo M, Wolfer DP, Hawkins RD, Schoonjans L, Kandel ER, Godfraind JM, Mulligan R, Collen D, Carmeliet P (1996) Mice lacking the gene encoding tissue-type plasminogen activator show a selective interference with late-phase longterm potentiation in both Schaffer collateral and mossy fiber pathways. Proc Natl Acad Sci USA 93:8699-8704.

Ingraham HA, Lawless GM, Evans GA (1986) The mouse Thy-1.2 gene: complete sequence and identification of an unusual promoter. J Immunol 136:1482-1489.

Inoue K, Koizumi S, Nakajima K, Hamanoue M, Kohsaka S (1994) Modulatory effect of plasminogen on NMDA-induced increase in intracellular free calcium concentration in rat cultured hippocampal neurons. Neurosci Lett 179:87-90.

Isaacson JS, Solis JM, Nicoll RA (1993) Local and diffuse actions of GABA in the hippocampus. Neuron 10:165-175.

Jalink K, Moolenaar WH (1992) Thrombin receptor activation causes rapid neural cell rounding and neurite retraction independent of classic second messengers. J Cell Biol 118:411-419.

Jones LS (1996) Integrins: possible functions in the adult CNS. Trends Neurosci 19:68-72.

Krystosek A, Seeds NW (1981) Plasminogen activator release at the neuronal growth cone. Science 213:1532-1534.

Larson J, Lynch G (1986) Induction of synaptic potentiation in hippocampus by patterned stimulation involves two events. Science 232:985-988.

Liu Y, Fields RD, Festoff BW, Nelson PG (1994) Proteolytic action of thrombin is required for electrical activity-dependent synapse reduction. Proc Natl Acad Sci USA 91:10300-10304.

Mansuy IM, van der Putten H, Schmid P, Meins M, Botteri FM, Monard D (1993) Variable and multiple expression of protease nexin-1 during mouse organogenesis and nervous system development. Development (Camb) 119:1119-1134.

Masukawa LM, Higashima M, Hart GJ, Spencer DD, O'Connor MJ (1991) NMDA receptor activation during epileptiform responses in the dentate gyrus of epileptic patients. Brain Res 562:176-180.

McDonald JW, Johnston MV (1990) Physiological and pathophysiological roles of excitatory amino acids during central nervous system development. Brain Res Rev 15:41-70.

McNamara JO (1994) Cellular and molecular basis of epilepsy. J Neurosci 14:3413-3425.

Meier CL, Dudek FE (1993) Spontaneous and stimulus-induced synchronized afterdischarges in the isolated CA1 of kainate-treated rats. Soc Neurosci Abstr 33:1464.

Meier R, Spreyer P, Ortmann R, Harel A, Monard D (1989) Induction of 
glia-derived nexin after lesion of a peripheral nerve. Nature 342:548-550.

Meiri N, Masos T, Rosenblum K, Miskin R, Dudai Y (1994) Overexpression of urokinase-type plasminogen activator in transgenic mice is correlated with impaired learning. Proc Natl Acad Sci USA 91:3196-3200.

Merlin LR, Wong RKS (1993) Synaptic modifications accompanying epileptogenesis in vitro: long-term depression of GABA-mediated inhibition. Brain Res 627:330-340.

Miles R, Wong RKS (1987) Inhibitory control of local excitatory circuits in the guinea pig hippocampus. J Physiol (Lond) 388:611-629.

Monyer H, Sprengel R, Schoepfer R, Herb A, Higuchi M, Lomeli H, Burnashev N, Sakmann B, Seeburg PH (1992) Heteromeric NMDA receptors: molecular and functional distinction of subtypes. Science 256:1217-1221.

Nick HP, Hofsteenge J, Rovelli G, Monard D (1990) Functional sites of glia-derived nexin (GDN): importance of the site reacting with the protease. Biochemistry 29:2417-2421.

Niclou S, Suidan HS, Brown-Luedi M, Monard D (1994) Expression of the thrombin receptor mRNA in rat brain. Cell Mol Biol 40:421-428.

Qian Z, Gilbert ME, Colicos MA, Kandel ER, Kuhl D (1993) Tissueplasminogen activator is induced as an immediate-early gene during seizure, kindling, and long-term potentiation. Nature 361:453-457.

Reinhard E, Meier R, Halfter W, Rovelli G, Monard D (1988) Detection of glia-derived nexin in the olfactory system of the rat. Neuron 1:387-394.

Reinhard E, Suidan HS, Pavlik A, Monard D (1994) Glia-derived nexin/ protease nexin-1 is expressed by a subset of neurons in the rat brain. J Neurosci Res 37:256-270.

Romanic AM, Madri JA (1994) Extracellular matrix-degrading proteinases in the nervous system. Brain Pathol 4:145-156.

Sakimura K, Kutsuwada T, Ito I, Manabe T, Takayama C, Kushiya E, Yagi T, Aizawa S, Inoue Y, Sugiyama H, Mishina M (1995) Reduced hippocampal LTP and spatial learning in mice lacking NMDA receptor $\epsilon 1$ subunit. Nature 373:151-155.

Sappino AP, Madani R, Huarte J, Belin D, Kiss JZ, Wohlwend A, Vasalli JD (1993) Extracellular proteolysis in the adult murine brain. J Clin Invest 92:679-685.

Sauer D, Allegrini PR, Kauffmann S, Lüthi A, Schmid P, Theilkäs W, van der Putten H (1996) Reduced infarct volume after focal cerebral ischemia in transgenic mice overexpressing IL-1 receptor antagonist. In: Pharmacology of cerebral ischemia (Krieglstein J, ed), pp 581-590. Stuttgart, Germany: Medpharm.

Schwartz MA, Schaller MD, Ginsberg MH (1995) Integrins: emerging paradigms of signal transduction. Annu Rev Cell Biol 11:549-599.

Scotti AL, Monard D, Nitsch C (1994) Re-expression of glia-derived nexin/protease nexin-1 depends on mode of lesion induction or terminal degeneration: observations after excitotoxin or 6-hydroxydopamine lesions of rat substantia nigra. J Neurosci Res 37:155-168.

Seeds NW, Williams BL, Bickford PC (1995) Tissue plasminogen activator induction in Purkinje neurons after cerebellar motor learning. Science 270:1992-1994.

Sheng M, Cummings J, Roldan LA, Jan YN, Jan LY (1994) Changing subunit composition of heteromeric NMDA receptors during development of rat cortex. Nature 368:144-147.

Silva AJ, Stevens CF, Tonegawa S, Wang Y (1992) Deficient hippocampal long-term potentiation in $\alpha$-calcium-calmodulin kinase II mutant mice. Science 257:201-206.
Smith-Swintosky VL, Zimmer S, Fenton II JW, Mattson M (1995) Protease nexin- 1 and thrombin modulate neuronal $\mathrm{Ca}^{2+}$ homeostasis and sensitivity to glucose deprivation-induced injury. J Neurosci 15:58405850 .

Sommer J, Gloor SM, Rovelli GF, Hofsteenge J, Nick H, Meier R, Monard D (1987) cDNA sequence coding for a rat glia-derived nexin and its homology to members of the serpin superfamily. Biochemistry 26:6407-6410.

Sommer J, Meyhack B, Rovelli G, Bürgi R, Monard D (1989) Synthesis of glia-derived nexin in yeast. Gene 85:453-459.

Staubli U, Vanderklish P, Lynch G (1990) An inhibitor of integrin receptors blocks long-term potentiation. Behav Neural Biol 55:1-5.

Stief A, Texido G, Sansig G, Eibel H, Le Gros G, van der Putten H (1994) Mice deficient in CD23 reveal its modulatory role in IgE production but no role in T and B cell development. J Immunol 152:3378-3390.

Stone SR, Nick H, Hofsteenge J, Monard D (1987) Glia-derived neuritepromoting factor is a slow binding inhibitor of trypsin, thrombin, and urokinase. Arch Biochem Biophys 252:237-244.

Suidan HS, Stone SR, Hemmings BA, Monard D (1992) Thrombin causes neurite retraction in neuronal cells through activation of cell surface receptors. Neuron 8:363-375.

Thompson SM, Gähwiler BH (1989) Activity-dependent disinhibition. I. Repetitive stimulation reduces IPSP driving force and conductance in the hippocampus in vitro. J Neurophysiol 61:501-511.

Tsirka SE, Gualandris A, Amaral DG, Strickland S (1995) Excitotoxininduced neuronal degeneration and seizure are mediated by tissue plasminogen activator. Nature 377:340-344.

Vaughan PJ, Pike CJ, Cotman CW, Cunningham DD (1995) Thrombin receptor activation protects neurons and astrocytes from cell death produced by environmental insults. J Neurosci 15:5389-5401.

Vidal M, Morris R, Grosveld F, Spanopoulou E (1990) Tissue-specific control elements of the Thy-1 gene. EMBO J 9:833-840.

Wagner S, Geddes J, Cotman C, Lau A, Gurwitz D, Isackson P, Cunningham D (1989) Protease nexin-1, an antithrombin with neurite outgrowth activity, is reduced in Alzheimer's disease. Proc Natl Acad Sci USA 86:8284-8288.

Wigström H, Gustafsson B (1983) Facilitated induction of hippocampal long-lasting potentiation during blockade of inhibition. Nature 301:603-604.

Williams K, Russell SL, Shen YM, Molinoff PB (1993) Developmental switch in the expression of NMDA receptors occurs in vivo and in vitro. Neuron 10:267-278.

Wood SA, Pascoe WS, Schmidt C, Kemler R, Evans MJ, Allen ND (1993) Simple and efficient production of embryonic stem cell-embryo chimeras by coculture. Proc Natl Acad Sci USA 90:4582-4585.

Xiao P, Bahr BA, Staubli U, Vanderklish PW, Lynch G (1991) Evidence that matrix recognition contributes to stabilization but not induction of LTP. NeuroReport 2:461-464.

Yamada N, Bilkey DK (1993) Induction of trypsin-induced hyperexcitability in the rat hippocampal slice is blocked by the $N$-methyl-Daspartate receptor antagonist, MK-801. Brain Res 624:336-338.

Zahedi K, Seldin MF, Rits M, Ezekowitz RAB, Whitehead AS (1991) Mouse IL-1 receptor antagonist protein. Molecular characterization, gene mapping, and expression of mRNA in vitro and in vivo. J Immunol 146:4228-4233. 